\title{
Molecular and Cellular Mechanisms of Cytotoxic Activity of Vanadium Compounds against Cancer Cells
}

\author{
Szymon Kowalski ${ }^{1}$ (D), Dariusz Wyrzykowski ${ }^{2}$ and Iwona Inkielewicz-Stępniak ${ }^{1, *(D)}$ \\ 1 Department of Medical Chemistry, Medical University of Gdansk, 80-211 Gdansk, Poland; \\ szymon.kowalski@gumed.edu.pl \\ 2 Faculty of Chemistry, University of Gdansk, 80-308 Gdansk, Poland; dariusz.wyrzykowski@ug.edu.pl \\ * Correspondence: iwona.inkielewicz-stepniak@gumed.edu.pl; Tel.: +48-58-3491450
}

Academic Editor: Jóhannes Reynisson FRSC

Received: 14 March 2020; Accepted: 8 April 2020; Published: 10 April 2020

\begin{abstract}
Discovering that metals are essential for the structure and function of biomolecules has given a completely new perspective on the role of metal ions in living organisms. Nowadays, the design and synthesis of new metal-based compounds, as well as metal ion binding components, for the treatment of human diseases is one of the main aims of bioinorganic chemistry. One of the areas in vanadium-based compound research is their potential anticancer activity. In this review, we summarize recent molecular and cellular mechanisms in the cytotoxic activity of many different synthetic vanadium complexes as well as inorganic salts. Such mechanisms shall include DNA binding, oxidative stress, cell cycle regulation and programed cell death. We focus mainly on cellular studies involving many type of cancer cell lines trying to highlight some new significant advances.
\end{abstract}

Keywords: vanadium compounds; cytotoxicity; cancer cells; molecular mechanisms; cellular mechanisms

\section{Introduction}

The discovery that metals are essential for the structure and function of biomolecules has given a completely new perspective on the role of metals in living organisms [1]. It has been determined that they can perform numerous processes that cannot otherwise be achieved. For instance, iron is essential for ribonucleotide reductase activity, an enzyme required for the rate limiting step of DNA synthesis [2]. Furthermore, over 300 enzymes that play important roles in gene expression include zinc in their structure (e.g., zinc-finger transcription factor) [3].

In the year 1965, Barnett Rosenberg serendipitously discovered the Pt(II) coordination compound, cis-[Pt $\left.\left(\mathrm{NH}_{3}\right)_{2} \mathrm{Cl}_{2}\right]$ (cisplatin) [4], one of the most successful metal-based drugs. This happened during studies on the effect of electric currents on bacteria. It has been found that cell division was inhibited by the production of cisplatin from the platinum electrodes [4]. Further studies on this platinum(II) agent indicated that it possessed antitumor activity and cisplatin was approved by the FDA in 1978 for the treatment of ovarian and testicular cancer [5]. Moreover, two derivatives of cisplatin were approved for treatment: carboplatin in 1989 for ovarian cancer [6] and oxaliplatin in 2002 for advanced colorectal cancer [7]. Both compounds exhibit fewer side effects and therefore have a lower toxicity as well as better retention in the body relative to cisplatin [8,9]. Unfortunately, despite these benefits, platinum-based chemotherapy is accompanied by side effects such as vomiting, neuropathy or nephrotoxicity $[10,11]$. However, an upwards trend for the market for platinum-based anticancer drugs has been maintained [12].

Nowadays, the design and synthesis of new metal-based compounds, as well as metal ion binding components, for the treatment of human diseases is one of the main aims of bioinorganic chemistry [13]. 
Metal-based molecules exhibit a wide range of unique properties, which cannot be achieved by typical organic compounds, such as a large amount of coordination numbers, accessible redox states or kinetic and thermodynamic characteristics [13]. Examples include metals for imaging, such as a gadolinium complex for MRI contrast [14] or positron emitting metal for positron emission tomography (PET) [15]. Moreover, metal ions coordinated to the organic ligand change the flexibility as well as geometry of the resulting complexes, causing more effective exploration of the activity space of the molecular target. Such a situation was observed in the case of the interactions of octahedral pyridocarbazole ruthenium(II) or iridium(III) complexes with the ATP-binding site of a protein kinase [16].

This new approach to the design and synthesis of new metal-based molecules has not excluded vanadium, which is the 18th most abundant element in our planet's crust and the 2nd most common element in sea water, in regard to transition metal concentration (between 30 and $35 \mathrm{nM}$ ), where it exists mainly in the form of $\mathrm{H}_{2} \mathrm{VO}_{4}^{-}$[17]. It is noteworthy that vanadium is also present in many living organisms including amanita mushrooms, marine Polychaeta fan worms or ascidians [17]. Importantly, vanadium deficiency in an animal diet produces many side effects: reduced fertility, increased rates of spontaneous abortion, decreased milk production and skeletal abnormalities [18]. Vanadium is constantly present in the human body in quantities of about $100 \mu \mathrm{g}$; however, it is not considered to be a micronutrient [17]. In the last 15 years, significant progress in the chemistry of vanadium has been made, particularly with regard to its therapeutic applications [19].

One of the areas of vanadium research is its potential anticancer activity. Recently, reviews describing its mechanism of anticancer activity have been published [19-22]. This current review aims to summarize more recent molecular and cellular mechanisms in the cytotoxic activity of many different synthetic vanadium complexes as well as inorganic salts. We focus mainly on cellular studies involving many types of cancer cell lines in an attempt to highlight some new significant advances.

\section{Mechanisms of Cytotoxicity}

\subsection{DNA: The Classical Target}

In classical chemotherapy, anticancer compounds directly target DNA, causing lesions and ultimately triggering cell death. This is in accordance with the cisplatin paradigm in which one of the major therapeutic pathways of the platinum-based complex is based on interaction with DNA to generate inter- and intra-strand crosslinks. This leads to transcription inhibition, disruption of the DNA repair system and ultimately to apoptosis [23]. Nowadays, it has been established that DNA is one of the primary pharmacological targets of many metal-based complexes [24]. The binding affinities of DNA-metal complexes are a key issue for understanding the mechanism of effective metal-based chemotherapeutic drugs.

Furthermore, in the case of vanadium, many studies on its interaction with DNA have been performed. Mohamadi et al. [25] have used electronic absorption spectroscopy, competitive fluorescence assay and cyclic voltametry studies to determine DNA binding activities. The obtained results showed groove binding of the mononuclear diketone-based oxido-vanadium(IV) complex (1) to the salmon sperm DNA, accompanied with a partial insertion of the ligand between the base stacks of the DNA. These experimental results have been confirmed by the results of molecular docking [25]. Additionally, the synthesized complex (1) exhibited cytotoxicity against breast, liver and colon cancer cell lines [25]. Another study on the diketone-based oxovanadium complexes ( 2 and 3 ) (containing trifluoropentanedione and trifluoro-1-phenylbutanedione) has shown that investigated complexes preferred minor groove binding with DNA [26]. Interestingly, a non-oxido vanadium(IV) complex with a catechol-modified 3,3'-diindolylmethane (4) exhibited stronger DNA binding than cisplatin [27]. Importantly, Fik et al. [28] have demonstrated that vanadium complexes with dimethylterpyridine (5 and 6) exhibited cytotoxic activity against human cervical carcinoma cells by direct interactions with DNA, thus increasing the level of arrest cells in stage G2/M. The DNA interaction ability has been determined also for the phenantroline vanadium complex (7-10) with simultaneous cytotoxic 
activity against human ovarian and breast carcinoma cells [29]. Furthermore, Rui et al. [30] has shown that vanadium complexes derived from thiosemicarbazones and fluoro-phenanthroline derivatives (11-13) interacted with calf-thymus DNA (CT-DNA) through a non-classical intercalative mode and they could efficiently cleavage plasmid pBR322 DNA upon exposure to ultraviolet light. Additionally, all investigated complexes exhibited anti-proliferative activity against many human tumor cell lines [30]. A similar study has been performed for oxidovanadium(IV) phenanthroimidazole derivatives (14-17), which could bind with CT-DNA and which cleaved supercoiled plasmid DNA in the presence of $\mathrm{H}_{2} \mathrm{O}_{2}$, and also exhibited cytotoxicity against a cervical cancer cell line by inducing apoptosis [31]. The DNA binding activity has been determined for many other synthetic complexes including the vanadium(V)-pyridylbenzimidazole complex (18) [32], mixed-ligand oxidovanadium(V) hydrazone complexes (19 and 20) [33] or VO(II)-Perimidine [1H-Benzo(de)quinazoline] (21-25) complexes [34].

An interesting approach to anticancer therapy provides photodynamic therapy (PDT) which is based on selectively damaging the photo-exposed cancer cells, leaving the unexposed healthy cells unaffected [35]. Kumar et al. [36] have designed an oxidovanadium(IV) complex with a 4,4-difluoro-4-bora-3a,4a-diaza-s-indacene (BODIPY)-based photosensitizer (26 and 27) for its PDT action, which showed dual activity: light-activated $\mathrm{VO}^{2+}$-DNA crosslink formation and singlet oxygen $\left({ }^{1} \mathrm{O}_{2}\right)$ induced mitochondria-targeted PDT. Interestingly, the BODIPY-based vanadium complex (27) exhibited remarkable photocytotoxicity against cervical and breast cancer cell lines via apoptotic pathway in visible light (400-700 nm) compared with low dark toxicity [36]. In other research, DNA melting and comet assay studies suggested the formation of DNA crosslinks by terpyridyl oxidovanadium(IV) complexes (28 and 29), and this effect was observed upon irradiation with visible light [37]. Additionally, neutral oxidovanadium(V) complexes with different organic ligands (30-33) had DNA binding propensity and it was shown that these interacted with CT-DNA through minor groove binding mode; however, the complex with isonicotinoylhydrazone of 2-hydroxy acetophenone (32) showed the highest photo-induced DNA cleavage activity [38].

Importantly, many indirect mechanisms that affect DNA structure and stability have been determined. Topoisomerases are enzymes that control the topological state of DNA through the re-joining or breaking of DNA strands [39]. There are two classes of topoisomerases: type I enzymes, which are able to transiently nick one of the two DNA strands, and type II enzymes which act by nicking both DNA strands and whose activity is ATP-dependent [39]. Research has shown that a oxidovanadium(IV) complex with silibinin (34) inhibited relaxation activity of human topoisomerase IB in a dose-dependent manner. However, the inhibition was incomplete, suggesting that the inhibitory effect of the vanadium compound is reversible [40].

The structure and activity of DNA-binding vanadium compounds are summarized in Table 1. Vanadium complexes may also cause indirect DNA damage by generating reactive oxygen species (ROS) resulting in oxidative stress. This is discussed in the following subsection.

Table 1. Structures and mechanism of action DNA-binding vanadium compounds ( $\mathrm{K}_{\mathrm{b}}$-binding constant).

\begin{tabular}{|c|c|c|}
\hline Structure & Activity & References \\
\hline 1 & 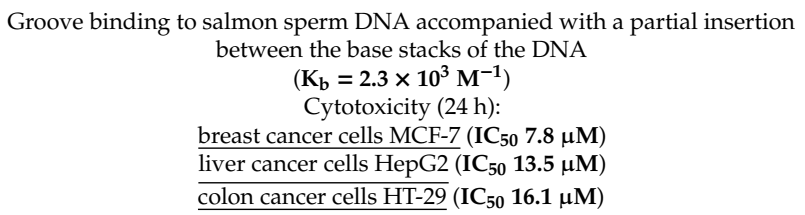 & [25] \\
\hline
\end{tabular}


Table 1. Cont

\begin{tabular}{|c|c|c|}
\hline Structure & Activity & References \\
\hline
\end{tabular}

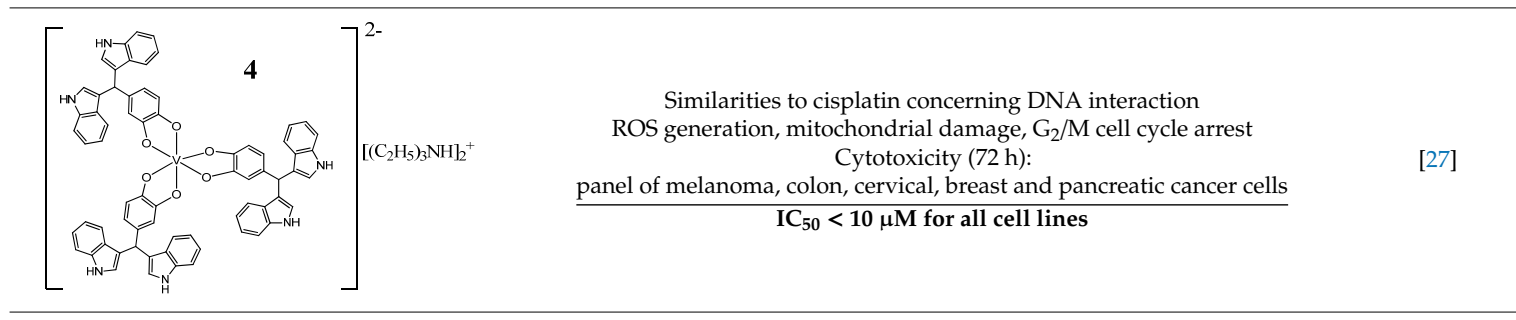

Intercalation as the way of DNA binding
$\mathrm{G}_{2} / \mathrm{M}$ cell cycle arrest
Cytotoxicity (48 h):
cervical cancer cells HeLa
(5: $\mathrm{IC}_{50} 42.9 \pm 1.5 \mu \mathrm{M}$
6: $\mathrm{IC}_{50} 33.2 \pm 0.9 \mu \mathrm{M}$ )
breast cancer cells T-47D
(5: $\mathrm{IC}_{50} 38.0 \pm 1.6 \mu \mathrm{M}$
6: $\left.\mathrm{IC}_{50} 42.3 \pm 1.8 \mu \mathrm{M}\right)$
Lung cancer cells A549
(5: $\mathrm{IC}_{50} 87.6 \pm 2.4 \mu \mathrm{M}$
6: $\mathrm{IC}_{50}>100 \mu \mathrm{M}$ )

\begin{tabular}{|c|c|c|}
\hline $\begin{array}{ll}11 \mathrm{VO}(\mathrm{hntdtsc})\left(\boldsymbol{\omega}-\mathrm{CF}_{3} \mathrm{PIP}\right) & \mathbf{R}_{\mathbf{1}}=\mathrm{CF}_{3}, \mathbf{R}_{\mathbf{2}}=\mathrm{H}, \mathbf{R}_{\mathbf{3}}=\mathrm{H} \\
\mathbf{1 2} \mathrm{VO}(\mathrm{hntdtsc})\left(\boldsymbol{m}-\mathrm{CF}_{3} \mathrm{PIP}\right) \mathbf{R}_{\mathbf{1}}=\mathrm{H}, \mathbf{R}_{\mathbf{2}}=\mathrm{CF}_{3}, \mathbf{R}_{\mathbf{3}}=\mathrm{H} \\
\mathbf{1 3} \mathrm{VO}(\mathrm{hntdtsc})\left(\boldsymbol{p}-\mathrm{CF}_{3} \mathrm{PIP}\right) & \mathbf{R}_{\mathbf{1}}=\mathrm{H}, \mathbf{R}_{\mathbf{2}}=\mathrm{H}, \mathbf{R}_{\mathbf{3}}=\mathrm{CF}_{3}\end{array}$ & $\begin{array}{l}\text { Interaction with CT-DNA through a non-classical intercalative mode } \\
\text { cleavage plasmid pBR322 DNA upon exposure to ultraviolet light } \\
\text { Cytotoxicity }(48 \mathrm{~h}) \text { : } \\
\frac{\text { panel of cervical, breast and esophageal cancer cells }}{\text { IC }_{50} \text { range: } 0.31-6.15 \mu \mathrm{M}}\end{array}$ & [30] \\
\hline $\begin{array}{ll}14 \mathrm{VO}(\text { hntdtsc)(NPIP) } & \mathbf{R}=\mathrm{NO}_{2} \\
15 \mathrm{VO}(\text { hntdtsc)(CPIP) } & \mathbf{R}=\mathrm{Cl} \\
16 \mathrm{VO}(\text { hntdtsc)(MePIP) } & \mathbf{R}=\mathrm{CH}_{3} \\
17 \mathrm{VO}(\text { hntdtsc)(HPIP) } & \mathbf{R}=\mathrm{OH}\end{array}$ & $\begin{array}{c}\text { Binding with CT-DNA by an intercalation } \\
\mathrm{K}_{\mathrm{b}}=14: 1.53 \times 10^{5} \mathrm{M}^{-1} 15: 1.41 \times 10^{5} \mathrm{M}^{-1} \\
16: 1.05 \times 10^{5} \mathrm{M}^{-1} 17: 0.95 \times 10^{5} \mathrm{M}^{-1} \\
\text { cleave supercoiled plasmid DNA in the presence of } \mathrm{H}_{2} \mathrm{O}_{2} \\
\mathrm{G}_{0} / \mathrm{G}_{1} \text { cell cycle arrest }(14) \\
\text { Induction apoptosis in Hela cells (14) } \\
\text { Cytotoxicity }(24 \mathrm{~h}) \text { : } \\
\text { cervical cancer cells HeLa } \\
\left(14: \mathrm{IC}_{50} 1.09 \pm 0.16 \mu \mathrm{M}\right. \\
\left.15: \mathrm{IC}_{50} 10.36 \pm 1.23 \mu \mathrm{M}\right) \\
\text { bladder cancer cell BIU-87 } \\
\left(14: \mathrm{IC}_{50} 4.51 \pm 0.68 \mu \mathrm{M}\right. \\
\left.15: \mathrm{IC}_{50} 8.69 \pm 1.05 \mu \mathrm{M}\right) \\
\frac{\text { lung cancer cells SPC-A-1 }}{\left(14: \mathrm{IC}_{50} 7.61 \pm 0.55 \mu \mathrm{M}\right.} \\
\left.15: \mathrm{IC}_{50} 21.43 \pm 3.24 \mu \mathrm{M}\right)\end{array}$ & [31] \\
\hline
\end{tabular}


Table 1. Cont.

\begin{tabular}{|c|c|c|}
\hline Structure & Activity & References \\
\hline & $\begin{array}{l}\text { Interaction with DNA in a intercalative fashion }\left(\mathbf{K}_{\mathbf{b}}=\mathbf{2 . 7 6} \times 10^{\mathbf{5}} \mathbf{M}^{\mathbf{- 1}}\right) \\
\text { Cytotoxicity }(24 \mathrm{~h}): \\
\text { lung cancer cell A549 } \\
\text { breast cancer cells MCF-7 } \\
\text { keratinocyte cancer cell A431 } \\
\text { IC } \begin{array}{c}\text { for all cancer cell lines } 75 \mu \mathrm{M} \\
\text { normal human keratinocyte cells HaCaT }\end{array} \\
\text { IC } 50150 \mu \mathrm{M}\end{array}$ & [32] \\
\hline & 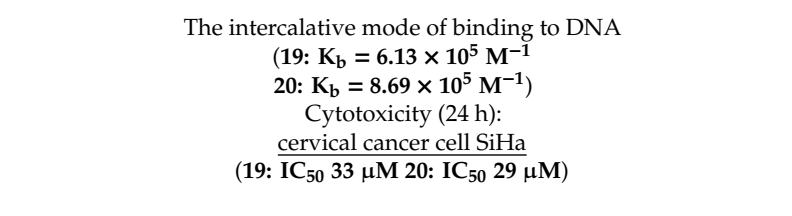 & [33] \\
\hline [(VO) $\left.2\left(\mathrm{SO}_{4}\right)_{2}(\mathbf{X})\right]\left(\mathrm{H}_{2} \mathrm{O}\right) \mathbf{X}$ & 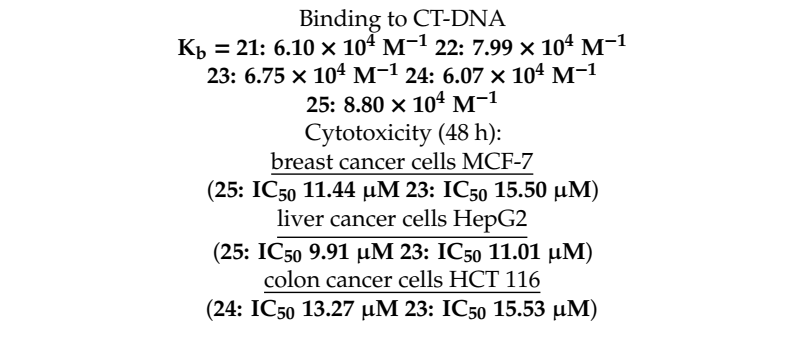 & [34] \\
\hline & 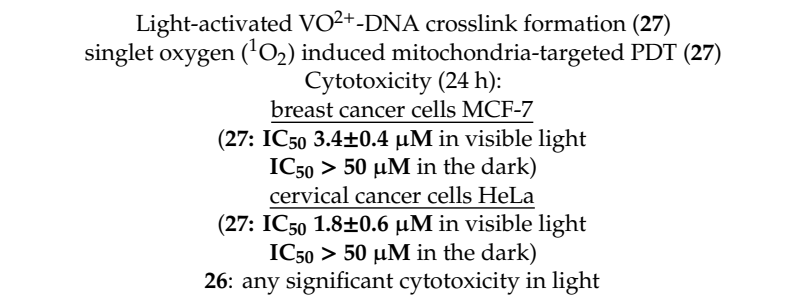 & [36] \\
\hline 2 & 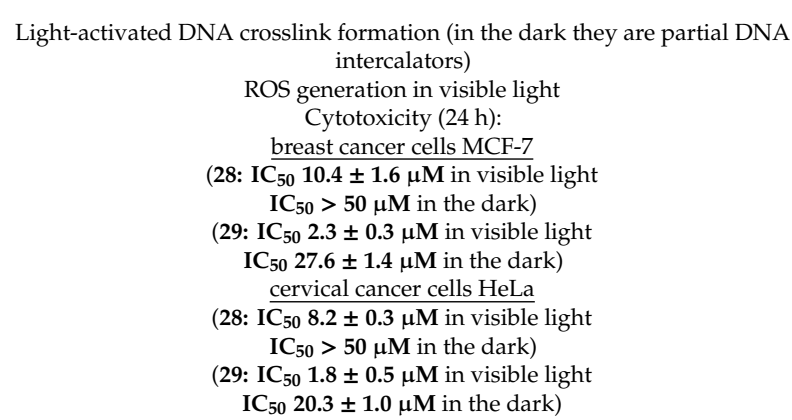 & [37] \\
\hline
\end{tabular}


Table 1. Cont.

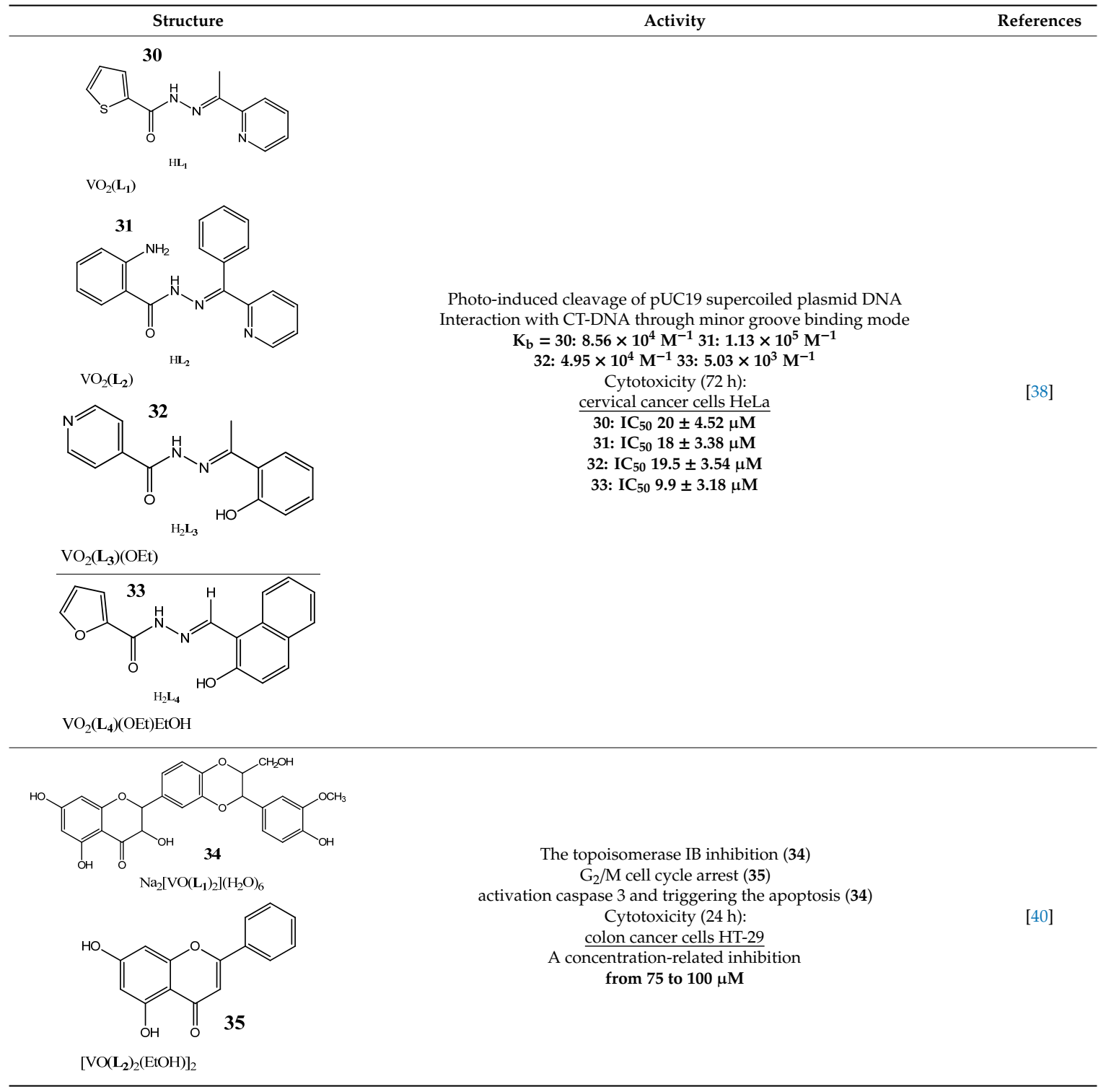

Bold and Underline: makes Table more readable.

\subsection{Oxidative Stress}

Oxidative stress is a complex issue [41]. This concept was first formulated in 1985 as "a disturbance in the prooxidant-antioxidant balance in favour of the former" [42]. The current definition takes into account the role of redox signaling and reads as follows: "An imbalance between oxidants and antioxidants in favour of the oxidants, leading to a disruption of redox signaling and control and/or molecular damage" [43]. The oxidants, which include free radicals, are molecules with a very short half-life and high reactivity. They can be oxygen-derived (ROS, reactive oxygen species), nitrogen-derived (RNS, reactive nitrogen species) or others (Figure 1) [41]. Several types of reactive species are generated in the body as a result of metabolic processes and the antioxidant system acts as an important counterbalance [44]. This system covers many enzymes (like superoxide dismutase, catalase or glutathione peroxidase), minerals, vitamins, glutathione, uric acid and others [44]. The central fact of oxidative stress is its double role: excessive oxidant challenge causes damage to biomolecules whereas a physiological level of oxidant challenge is essential for governing life processes through redox signaling [41]. In the case of cancer biology, an accelerated metabolism demands high ROS concentrations to maintain their high proliferation rate. Cancer cells develop different ways to increase 
ROS resistance including the execution of alternative pathways, which can avoid large amounts of ROS accumulation without compromising the energy demand [45]. Currently, the commonly used radio- and chemotherapeutic drugs influence tumor outcome through ROS modulation [45].

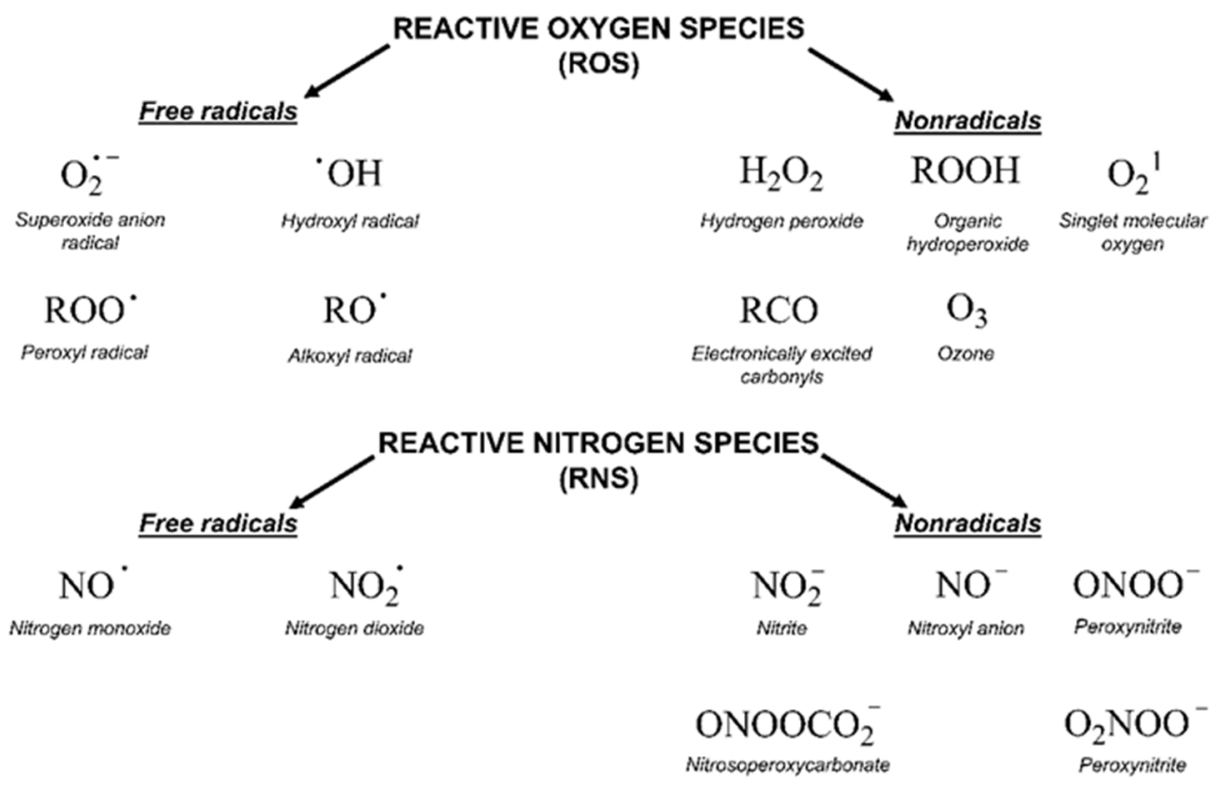

Figure 1. Chemical structure and nature of reactive oxygen (ROS) and nitrogen species (RNS).

Oxidative stress as a mechanism of the cytotoxic activity of vanadium-based compounds is well documented. In one of the most recent studies, vanadium salts, sodium metavanadate $\mathrm{NaVO}_{3}$ (36) and vanadium(IV) sulfate oxideVOSO 4 (37) significantly increased the ROS level in human lung cancer cells. However, the higher ROS level was induced by complexes containing vanadium(+IV) in the coordination center [46]. These results suggest that the efficacy of the ROS generation induced by vanadium compounds depends on the oxidation state of the vanadium cation presented in the coordination sphere of the complex [46]. For peroxovanadate complexes, the results are consistent. The polyacrylate derivative of peroxovanadate (38) inhibited growth of lung carcinoma cells by activating the axis of Rac1-NADPH oxidase leading to oxidative stress [47]. The vanadium complex with N-(2-hydroxyacetophenone) glycinate (39) triggered apoptosis in human colorectal carcinoma cells through mitochondrial outer membrane permeabilization, possibly by altering cellular redox status [48]. In the case of human pancreatic cancer cells, it has been shown that bis(acetylacetonato)-oxidovanadium(IV) complex (40) and sodium metavanadate (36) increased ROS generation; however, they did not induce a sustained increase of ROS generation, but the level of ROS reached a plateau instead [49]. Additionally, the results revealed that an intracellular feedback loop may be against the elevated ROS level, evidenced by the increased GSH content and the unchanged level of the antioxidant enzyme expression [49]. Oxidative stress was also induced in osteosarcoma cells by oxidovanadium(IV) complexes with glucose and naproxen (41 and 42) [50]. Leon et al. [51] have investigated the cytotoxicity of three oxidovanadium(IV) complexes (43 and 45) by use of the same type of cancer cells. The complex with phenanthroline (45) showed the highest cytotoxic activity which correlated with the strongest increase of ROS [51]. Interestingly, in studies performed by our group, the same vanadium complex (45-47) also induced the ROS generation in a human pancreatic cancer cell line [52]. In another study, an oxovanadium (IV/V) complex with a galactomannan derivative (polysaccharides) (48 and 49) showed cytotoxicity against a human liver cancer cell line by decreasing the mitochondrial membrane potential and increasing the ROS levels [53].

An interesting study has been performed by $\mathrm{Li}$ et al. [54] in which a vanadium dioxide nanocoating $\left(\mathrm{VO}_{2}\right.$-modified) quartz surface has been prepared. The obtained results showed that the $\mathrm{VO}_{2}$-modified 
quartz surface (releasing ions from surface) interrupted the mitochondrial electron transport chain and then elevated the intracellular ROS levels in the cholangiocarcinoma cells [54].

An interesting and intriguing study performed by Wang et al. [55] suggests that vanadium complexes with antioxidants $(35,40,50)$ should reduce their toxicities in human normal cells without affecting their antitumor activities in cancer cells (selective cytotoxicity). This is consistent with results for an oxidovanadium(IV) complex with 3-(3,4-Dihydroxycinnamoyl)quinic acid (51), which exhibited antioxidant activity as well as selective cytotoxicity against a human breast cancer cell line without increase of the ROS level [56]. The synthesis of vanadium complexes with flavonoids, well-known natural antioxidants [57,58], appears reasonable. Consequently, Naso et al. [59] have conducted a study on the oxidovanadium(IV) complex with flavonol morin (52). The new complex showed cytotoxic activity against breast cancer cell lines without generating reactive oxygen species in the cells and producing damage of DNA. Moreover, the complex did not affect the normal proliferation of the breast epithelial mammal cells [59]. These important results clearly demonstrate that the mechanism of cytotoxicity of vanadium compounds does not have to be ROS-dependent. On the other hand, many other flavonoid-based complexes showed the opposite mechanism. An oxidovanadium(IV) complex with apigenin (53) showed moderate cytotoxicity against lung and cervix cancer cell lines with simultaneous slight increments of ROS levels and decrease of the GSH/GSSG ratio [60]. Additionally, this cytotoxic activity was reverted when natural antioxidants were incubated with the complex [61]. In another study, an oxidovanadium(IV) complex with the flavonoid chrysin (54) caused a concentration-dependent inhibition of cell human osteosarcoma cells and ROS generation. The alterations in the GSH/GSSG ratio were proposed as the main mechanisms [61]. Besides, an oxidovanadium(IV) complex with flavonoid baicalin (55) also showed ROS-dependent cytotoxicity against a human lung cancer cell line [62].

Interestingly, an L-cysteine-based oxidovanadium(IV) complex (56) has been proposed as a promising chemoprotectant against oxidative stress and nephrotoxicity induced by cisplatin [63]. In this in vivo study, the vanadium complex exhibited strong nephroprotective efficacy by restoring antioxidant defense mechanisms [63]. A similar in vivo study has been performed for cyclophosphamide, that induces hepatotoxicity and genotoxicity in mice [64]. Oral administration of an L-cysteine-based oxidovanadium(IV) complex (56) significantly attenuated cyclophosphamide-induced oxidative stress in the liver as evident from levels of reactive oxygen species, nitric oxide and lipid peroxidation [64]. In addition, it restored the glutathione level and activities of antioxidant enzymes, and mitigated chromosomal aberrations, micronuclei formation, DNA fragmentation and apoptosis in bone marrow cells and DNA damage in lymphocytes [64].

In case of photodynamic therapy (PDT) (described in the DNA subsection), induction of oxidative stress has been documented. Ferrocenyl-terpyridine oxidovanadium(IV) complexes (57-60) exhibit photocytotoxic activity against breast and cervical cancer cells through ROS generation [65]. Moreover, investigated complexes show significant photocleavage of plasmid DNA in green light forming $\cdot \mathrm{OH}$ radicals [65]. The structures and activities of ROS-inducing vanadium compounds are summarized in Table 2.

Table 2. Structures and mechanism of action ROS-inducing vanadium compounds (ROS, reactive oxygen species; MMP, mitochondrial membrane potential; GSH/GSSG, reduced/oxidized glutathione).

Activity
Leferences


Table 2. Cont.

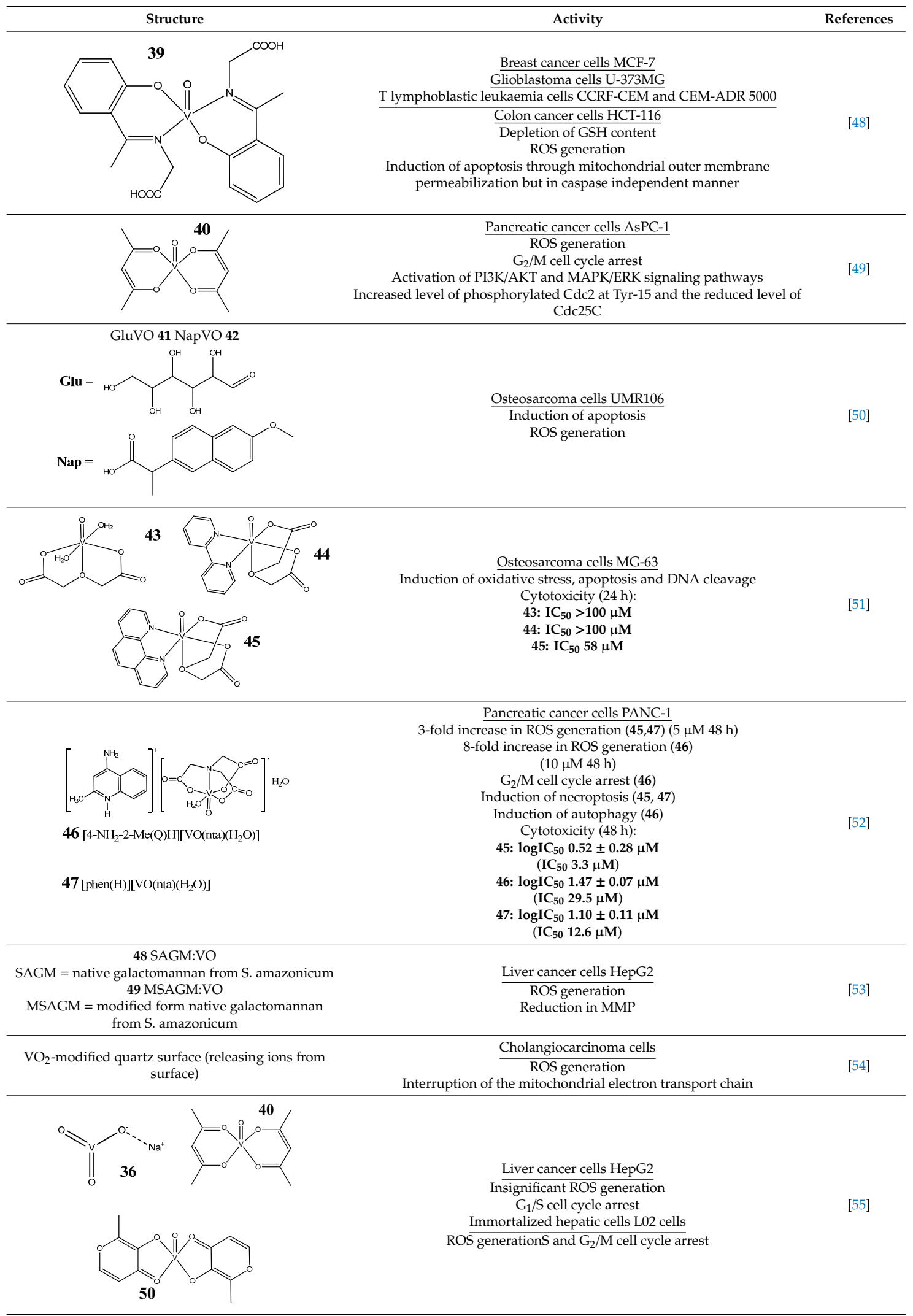


Table 2. Cont.

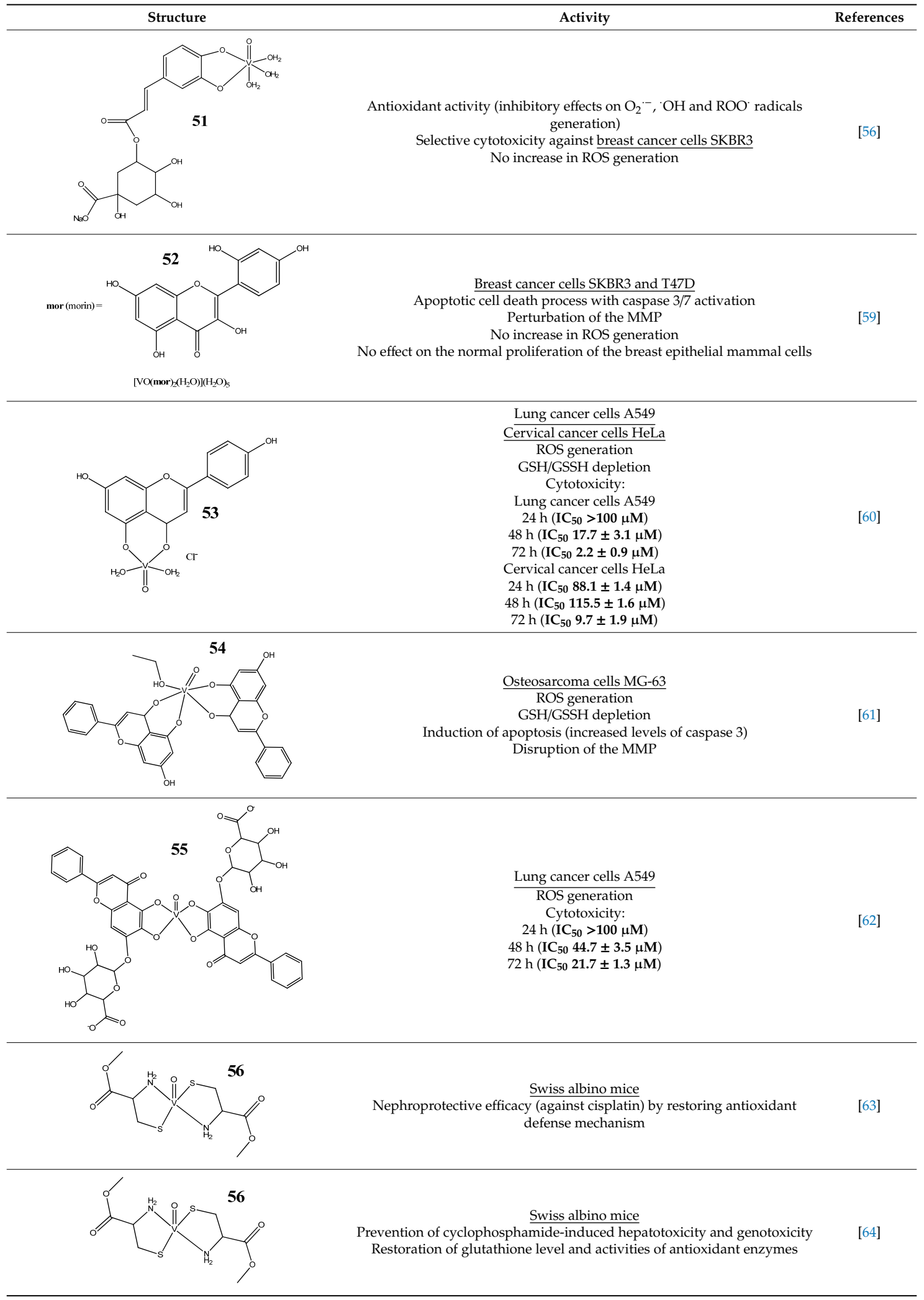


Table 2. Cont.

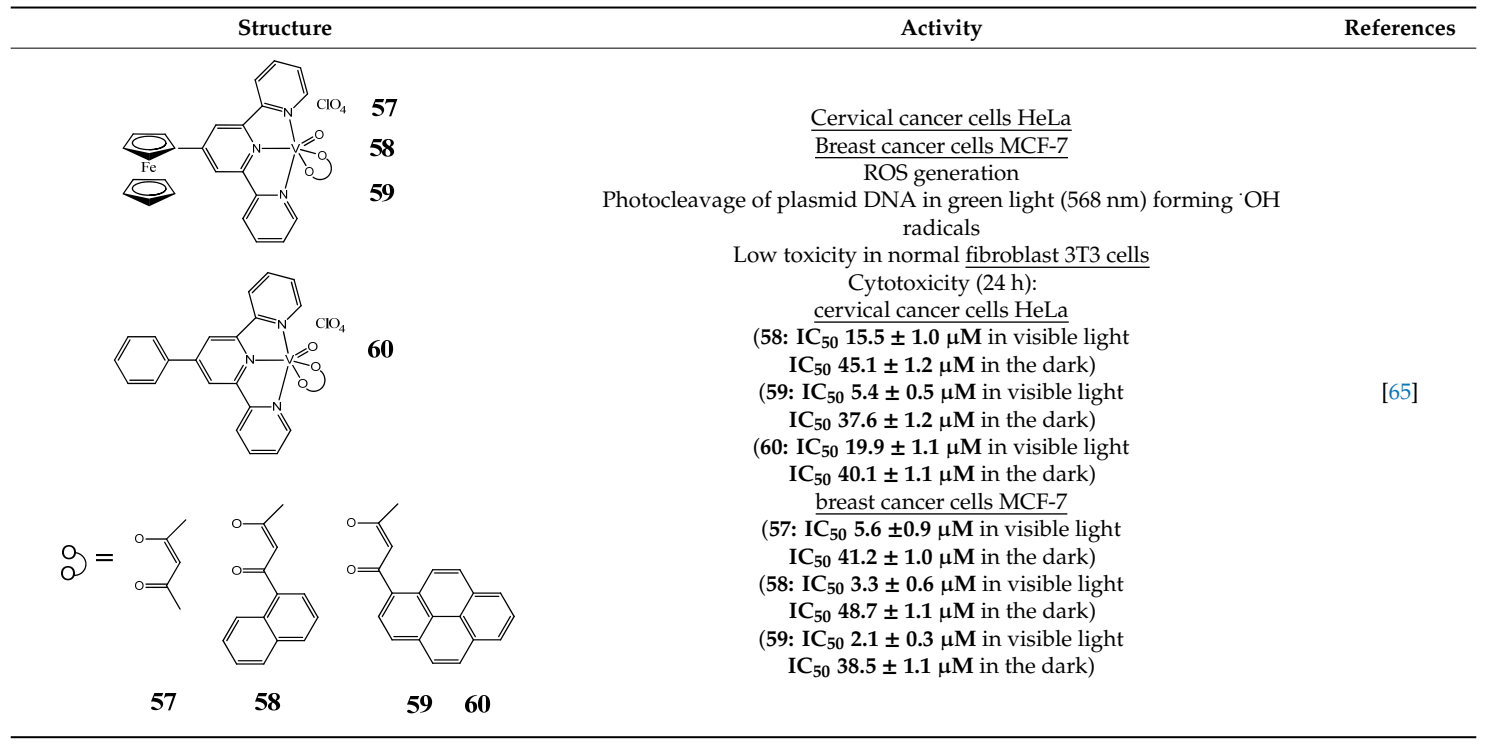

Bold and Underline: makes Table more readable.

The free radical generation may be associated with DNA damage. It has been determined that vanadium(IV) (37) caused molecular oxygen-dependent DNA strand breaks as well as molecular oxygen dependent 2 '-deoxyguanosine (dG) hydroxylation to form 8-hydroxyl-2'-deoxyguanosine (8-OHdG) [66]. Moreover, incubation of $\mathrm{VOSO}_{4}$ (37) with dG in argon did not generate any significant amount of 8-OHdG [66]. For some vanadium-based complexes described above, DNA damage with simultaneous ROS generation was also recognized [26,27,36,37,47,48] (Tables 1 and 2). DNA lesions lead to cell cycle disruption and ultimately to cell death, which are discussed in the following subsections.

\subsection{Cell Cycle Arrest}

The cell cycle is the sequence of stages through which a cell passes between one cell division and the next. This process includes four stages: $G_{1}, S, G_{2}$ and $M$ phases [67]. In $S$ phase, the genetic material is replicated (DNA synthesis), whereas $M$ phase includes mitosis and cytokinesis. $G_{1}$ and $\mathrm{G}_{2}$ are "gaps" during which time cells prepare for the next phase [67]. The passage to the different phase is coordinated by a set of the proteins: cyclins and their associated cyclin-dependent kinases (cdks) [68]. Cyclin/cdk complexes play a key role in checkpoints, which monitor progression through each cell cycle phase and maintain the correct order of events [68]. If aberrant or incomplete cell cycle events (e.g., DNA damage) are detected, checkpoint pathways trigger cell cycle arrest until the problem is resolved [68]. During cell cycle arrest, cells can repair cellular damage, spread an exogenous cellular stress signal or increase availability of essential growth factors, hormones, or nutrients [68]. The system of cell cycle regulation also includes the CDK inhibitors (CDKIs), which are divided into two families: Ink4 family (p16, p15, p18 and p19) and the Cip/Kip family (p21, p27, p57) [69]. Moreover, the p53 protein also plays an important role in cell cycle regulation. It has been shown that p53 and p21 are necessary to maintain a $G_{2}$ arrest following DNA damage $[70,71]$. The cdc25 phosphatase family is another group which activates cyclin-dependent kinases through dephosphorylation [72]. Deregulation of the cell cycle characterizes cancer cells, which underlies the aberrant cell proliferation and promotes genetic instability [67].

The impact of vanadium-based compounds on cell cycle progression was determined and described earlier [73]. More recent research is coherent with previous studies and supplements our knowledge in this area. Liu et al. [74] have shown that sodium metavanadate (36) caused $\mathrm{G}_{2} / \mathrm{M}_{\text {cell }}$ cycle arrest in prostate cancer cells, which is evidenced by the increase in the level of phosphorylated cdc2(cdk1) at its inactive Tyr-15 site. Importantly, the results revealed that ROS-mediated degradation 
of cdc25C is responsible for vanadate-induced $\mathrm{G}_{2} / \mathrm{M}$ cell cycle arrest [74]. Furthermore, sodium orthovanadate (61) induced $\mathrm{G}_{2} / \mathrm{M}$ phase cell cycle arrest in a human thyroid carcinoma cell line [75]. Interestingly, the same vanadium salt (61) decreased the expression of cyclin D1 and increased the expression of p21 protein in papillary thyroid carcinoma-derived cells; however, the cell cycle profile was similar to the untreated cells [76]. In other study in malignant melanoma cell lines, the inorganic anion vanadate $(V)(62)$ arrested the cell cycle in $G_{2} / M$ phase whereas pirydone-based vanadium complex (63-65) arrested it in the $G_{0} / G_{1}$ phase [77]. Furthermore, both compounds (62 and 63) induced dephosphorylation of the Retinoblastoma protein $(\mathrm{Rb})$ and together had a pronounced increase of cyclin-dependent kinase inhibitor p21 protein expression [78]. These studies highlight the importance of the chemical form of vanadium-based complexes in determining their mechanism of action. In our team study, the oxidovanadium complex containing quinolinium cation (66) induced cycle arrest in the $\mathrm{G}_{2} / \mathrm{M}$ phase with simultaneous triggering of the p53/p21 pathway in pancreatic cancer cell lines [79]. Induction of the p53/p21 pathway was also determined in cervical cancer cells treated by vanadium complexes of nicotinoyl hydrazine (67 and 68) [80]. An oxidovanadium complex with phenanthroline (69-72) arrested the cell cycle in the $S$ and $\mathrm{G}_{2} / \mathrm{M}$ phases in hepatocellular carcinoma cell lines [81]. Contrary to this study, other phenanthroline-based vanadium complex (73 and 74) caused a $G_{0} / G_{1}$ phase cell cycle arrest in the same type of cancer cell lines [82]. Additionally, $G_{0} / G_{1}$ phase cell cycle arrest, induced by organic vanadium complexes (75-78), was shown in human neuroblastoma cells [83]. Cell cycle arrest in $S$ phase has been determined in esophageal squamous carcinoma cell lines treated by sodium vanadate (61) [84]. Additionally, diaminotris(phenolato) vanadium(V) complexes (79 and 80) arrested the cell cycle at the $S$ phase in human colon cancer and ovarian carcinoma cell lines [85]. All above studies clearly suggest that the mechanism of cell cycle disruption depends not only on organic ligands and the spatial structure of vanadium-based compounds but also on the type of cancer cell lines, which may be associated with their genetic background. The structures and activity of cell-cycle-disrupting vanadium compounds are summarized in Table 3.

Some studies, described in the previous subsection, have found a connection between DNA binding and cell cycle arrest $[27,28,31,40]$ (Table 1 ) as well as oxidative stress and cell cycle progression $[49,52,55]$ (Table 2). Wu et al. [49] have demonstrated that the ROS-induced sustained MAPK/ERK activation contributed to vanadium-compound-induced $\mathrm{G}_{2} / \mathrm{M}$ cell cycle arrest in pancreatic cancer cells. Additionally, cell cycle disruption with simultaneous ROS generation was shown in lung carcinoma [47] and osteosarcoma cell lines [61].

Table 3. Structures and mechanism of action of cell-cycle-disrupting vanadium compounds (ROS, reactive oxygen species; MMP, mitochondrial membrane potential).

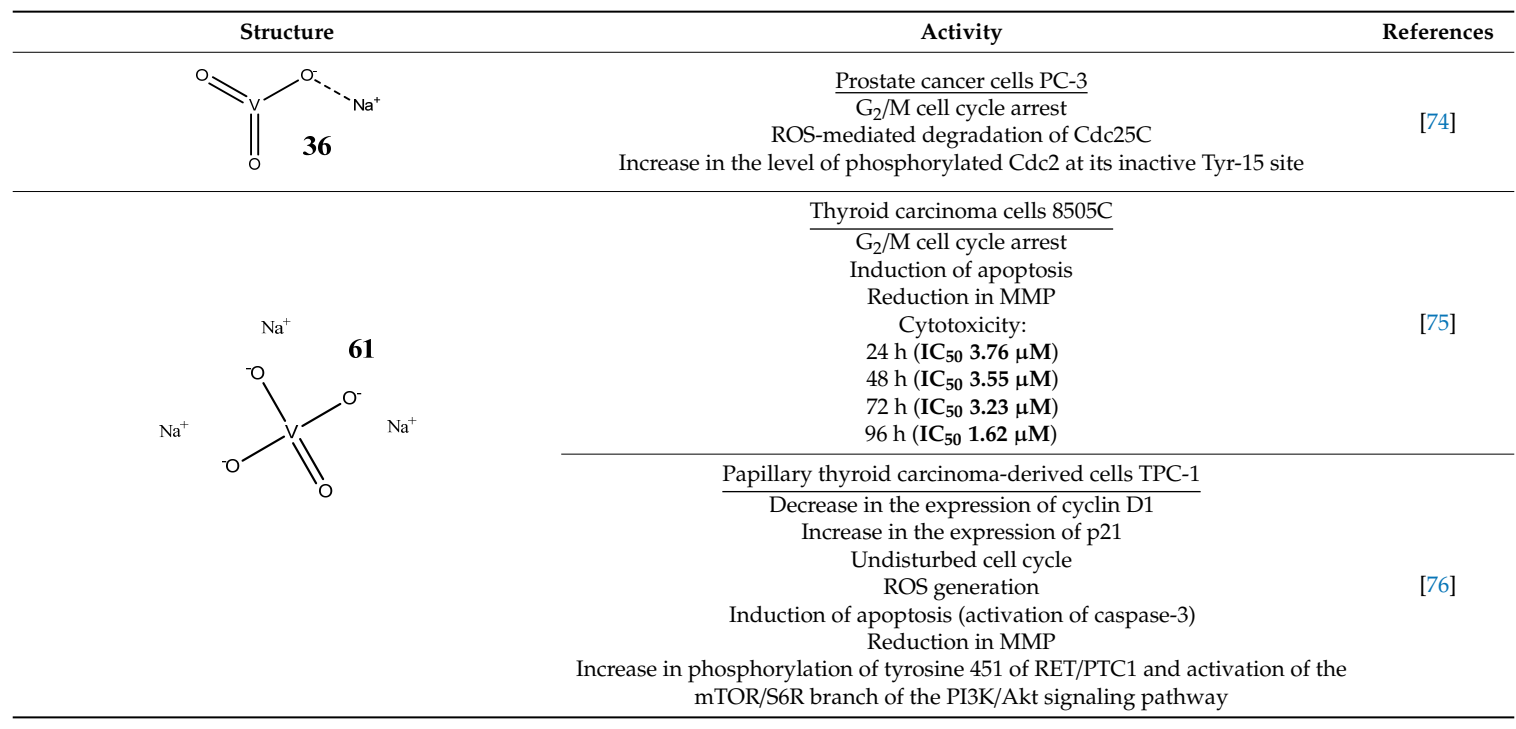


Table 3. Cont

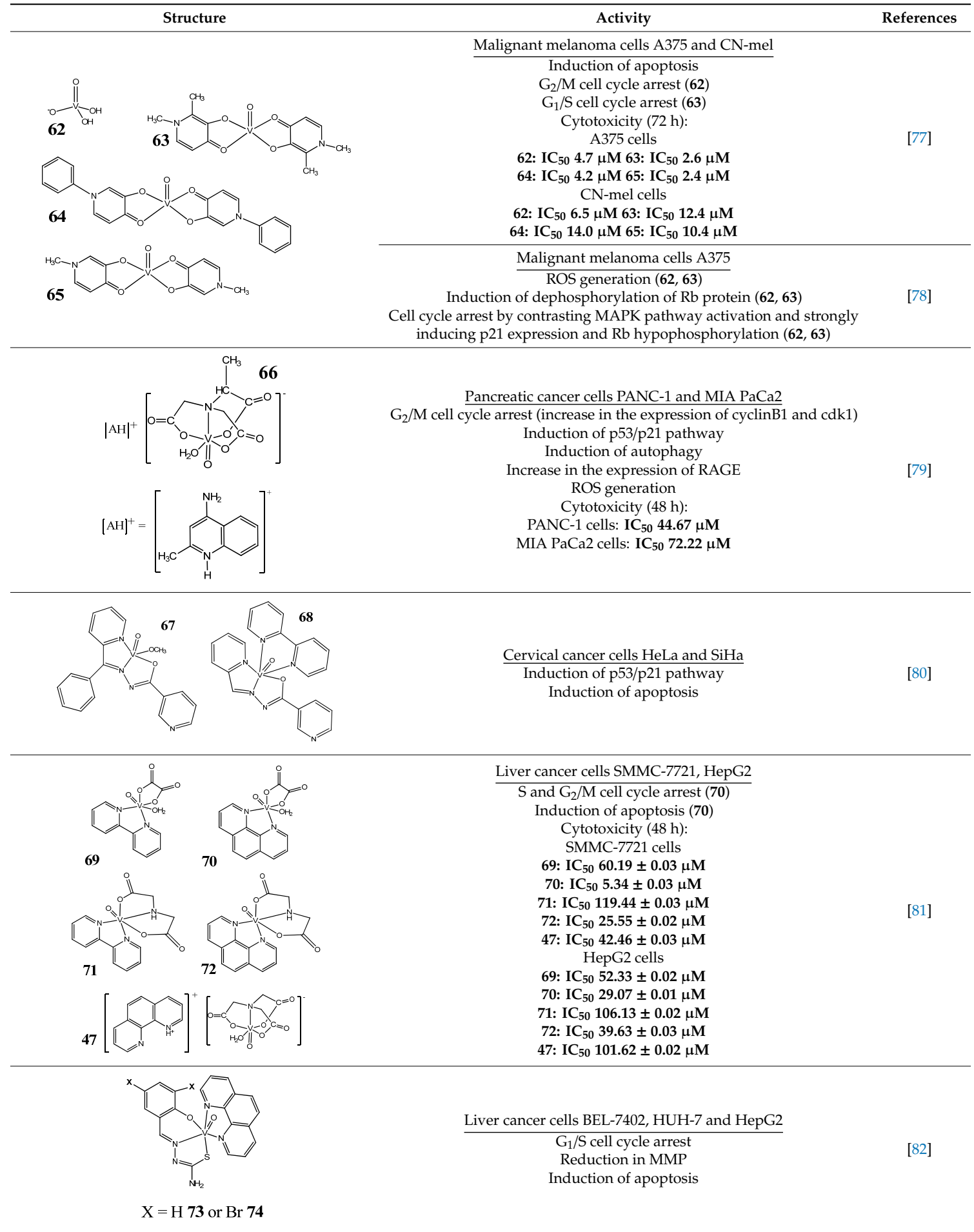


Table 3. Cont.

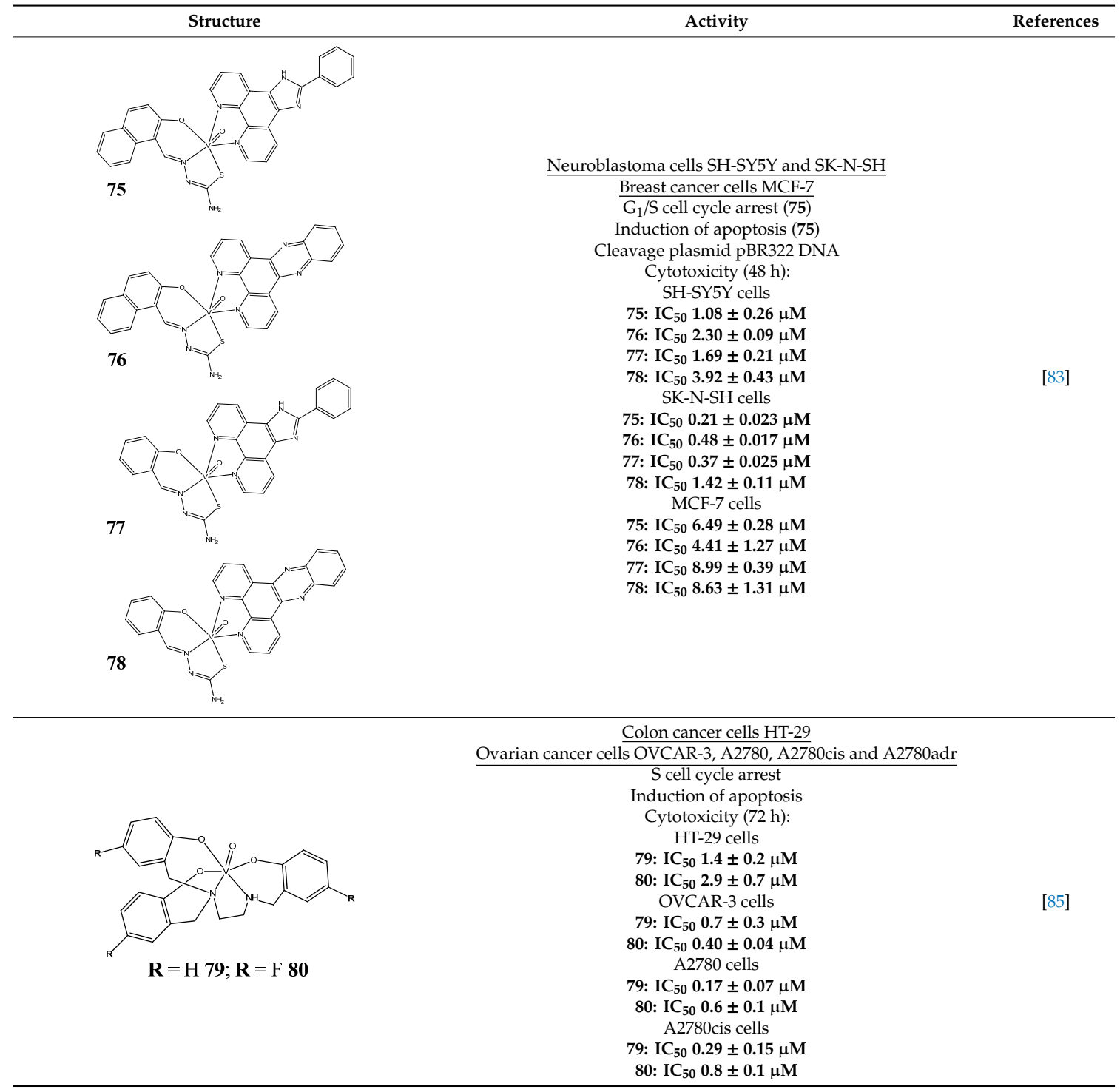

Bold and Underline: makes Table more readable.

\subsection{Programed Cell Death}

Apoptosis is programed cell death with distinct genetic and biochemical pathways that play a critical role in development and homeostasis in normal tissues [86]. Apoptosis is caused by special proteases, caspases, which specifically target cysteine aspartyl [86]. Moreover, there are two main pathways to apoptotic cell death: the extrinsic pathway mediated by membrane death receptors and the intrinsic pathway mediated by the mitochondria [86]. Under many stressful conditions, like activation of the DNA damage checkpoint pathway, apoptosis can remove potentially harmful DNA-damaged cells in order to block carcinogenesis [87]. Defects in this process can cause cancer. The cancer cells use some of several molecular mechanisms to suppress apoptosis and acquire resistance to apoptotic agents including the downregulation or mutation of proapoptotic proteins such as BAX expression or the expression of antiapoptotic proteins such as Bcl-2 [87].

Induction of apoptotic cell death by vanadium-based compounds is well established. Sodium orthovanadate $\left(\mathrm{Na}_{3} \mathrm{VO}_{4}\right)(\mathbf{6 1})$ induced apoptosis in the oral squamous cell carcinoma cell line [88] as well as in human anaplastic thyroid carcinoma cells [75]. Moreover, orthovanadate (61) induced typical features of apoptosis including DNA fragmentation, loss of mitochondrial membrane potential 
and activation of caspase-3 in thyroid cancer cells harboring RET/PTC1 (oncogenic chromosomal rearrangements) [76].

In the case of some vanadium-based complexes, it has been exhibited that vanadium complex (81) induced apoptosis in gastric cancer lines via the mediation of the intrinsic apoptotic pathway (upregulation of Bax, PARP and caspase-3/9) [89]. Moreover, vanadium complex with the flavonoid quercetin (82) upregulated the expressions of $\mathrm{p} 53$ and caspase 3 and 9 with simultaneous downregulation of Akt, mTOR and VEGF expressions in human breast cancer cell lines [90]. Additionally, complexes with flavonoid quercetin (82) induced apoptosis in a breast cancer animal model [90]. On the contrary, a vanadium complex containing phenanthroline (83) triggered apoptosis by activation of both extracellular (through caspase 8) and intracellular (through caspase 9) apoptosis-inducing pathways leading to activation of downstream caspase 3 in the human T-leukemic cells [91]. A vanadium complex with a modified phenol group (84) induced apoptosis in liver hepatocellular carcinoma cells using the p53-p21 pathway-dependent way [92]. A p53-dependent apoptotic mechanism, induced by vanadium complexes of nicotinoyl hydrazine (67 and 68), was also determined in cervical cancer cells [80]. A complex study, using the functional proteomic analysis, has been performed on human osteosarcoma cells. The results showed that an oxidovanadium(IV) complex with the clioquinol (85) induced upregulation of proteins such as caspase 3, caspase 6, caspase 7, caspase 10, caspase 11, Bcl-x and DAPK, as well as downregulation of ones such as PKB/AKT and DIABLO [93]. Moreover, cell signaling pathways involved in several altered pathways related to the PKC and AP2 family were identified [93]. An interesting study has been performed using photodynamic therapy. Oxidovanadium(IV) vitamin-B6 Schiff base complexes (86 and 87 ) showed remarkable apoptotic photocytotoxicity in visible light and specific localization to endoplasmic reticulum (ER) in ovarian and breast cancer cell lines [94].

Induction of oxidative stress may lead to apoptotic cell death [95]. Vanadium inorganic salts, namely $\mathrm{NaVO}_{3}$ (36) and $\mathrm{VOSO}_{4}$ (37), exhibited apoptotic-inducing cytotoxicity against non-small lung cell carcinoma cells with simultaneous increase of ROS level [46]. Pisano et al. have shown that both the inorganic anion vanadate(V) (62) and the vanadium complex with pyridinonate (63) induced apoptosis through generation of ROS in malignant melanoma cells [78]. Interestingly, a vanadium-Schiff base complex (39) actuated apoptosis through mitochondrial outer membrane permeabilization in human colorectal carcinoma cells; however, this was in a caspase-independent manner, possibly by altering cellular redox status and inflicting DNA damage [48].

Evading programed cell death is one of the hallmarks of cancer [96]. Therefore, seeking an alternative nonapoptotic form of programed cell death is required [97-99]. It has been found that dioxovanadium complexes with substituted salicylaldehyde derivatives (88 and 89 ) induced cell death in colon cancer cells via the activation of RIPK3 and necroptosis pathway [100]. Furthermore, we have determined that vanadium complexes with phenanthroline $(45,47)$ also trigger the necroptosis pathway in a human pancreatic ductal adenocarcinoma cell line [52]. In another study, we have found that an oxidovanadium complex with quinolinium cation (66) induced autophagic process in pancreatic cancer cells with simultaneous increase in the RAGE protein level [79]. Autophagy was also detected in vanadium-treated (90) breast cancer cells [101]. An interesting study has been performed in hypoxic conditions. A complex of the hydrolysate of galactomannan with oxidovanadium(IV) (91) exhibited strong apoptotic activity against hepatocellular carcinoma cell lines under normoxic conditions. However, this was completely lost under hypoxic conditions [102]. This was explained by strong induction of autophagy, which was characterized as a pro-survival mechanism in hypoxia [102]. Autophagy may play a dual role in cancer cells and therefore both its induction and inhibition can provide a valuable therapeutic strategy [99]. Structures and mechanisms of cell death induced by vanadium compounds are summarized in Table 4. Many DNA-binding, ROS-inducing and cell-cycle-disrupting vanadium compounds induce programed cell death and are described in Tables 1, 2 and 4. 
Table 4. Structures and mechanism of cell death induced by vanadium compounds (EMT: the epithelial-mesenchymal transition).

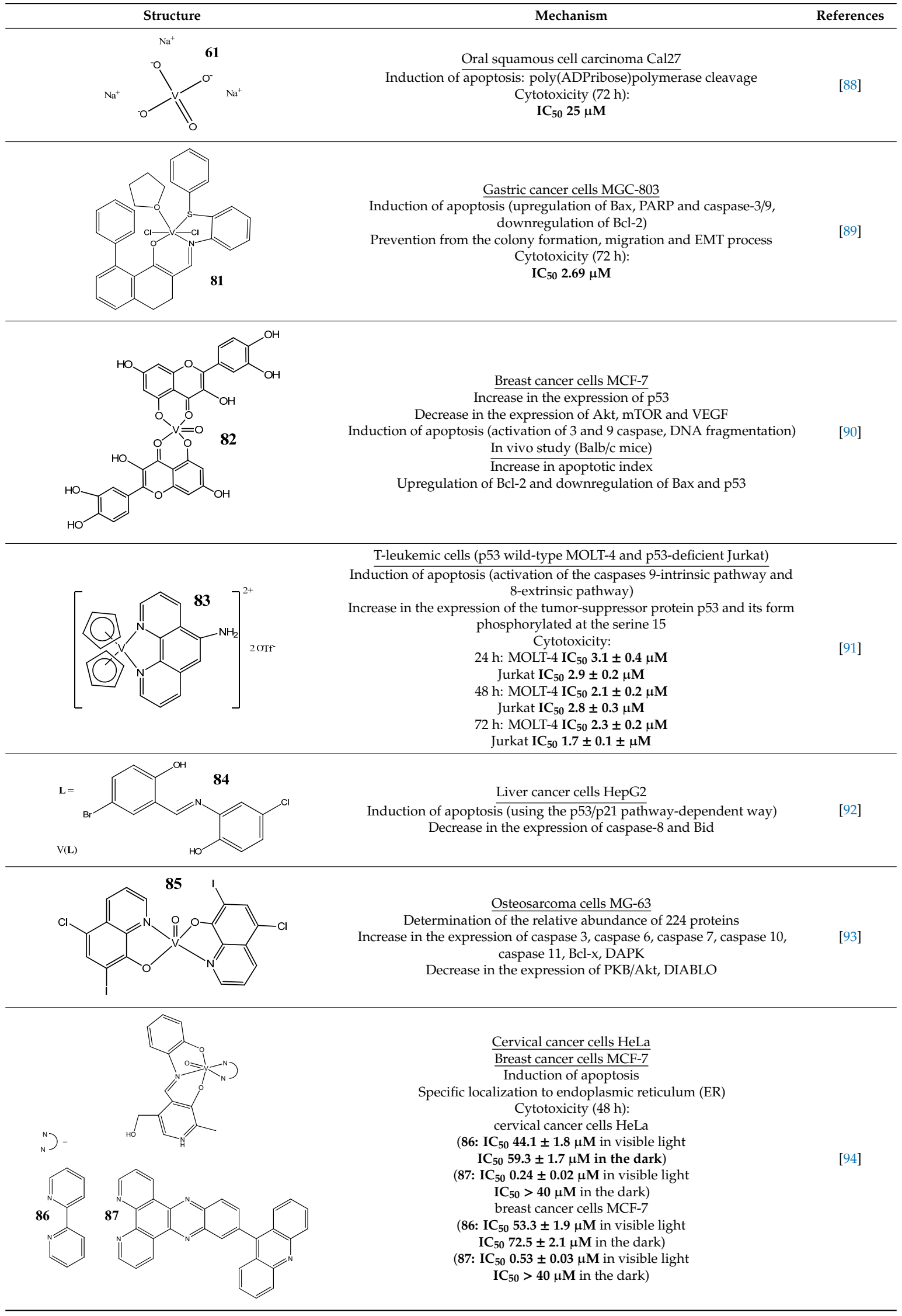


Table 4. Cont.

Refhanism
[100]

Bold and Underline: makes Table more readable.

Summary of the described molecular and cellular mechanisms of vanadium compounds are illustrated in Figure 2.

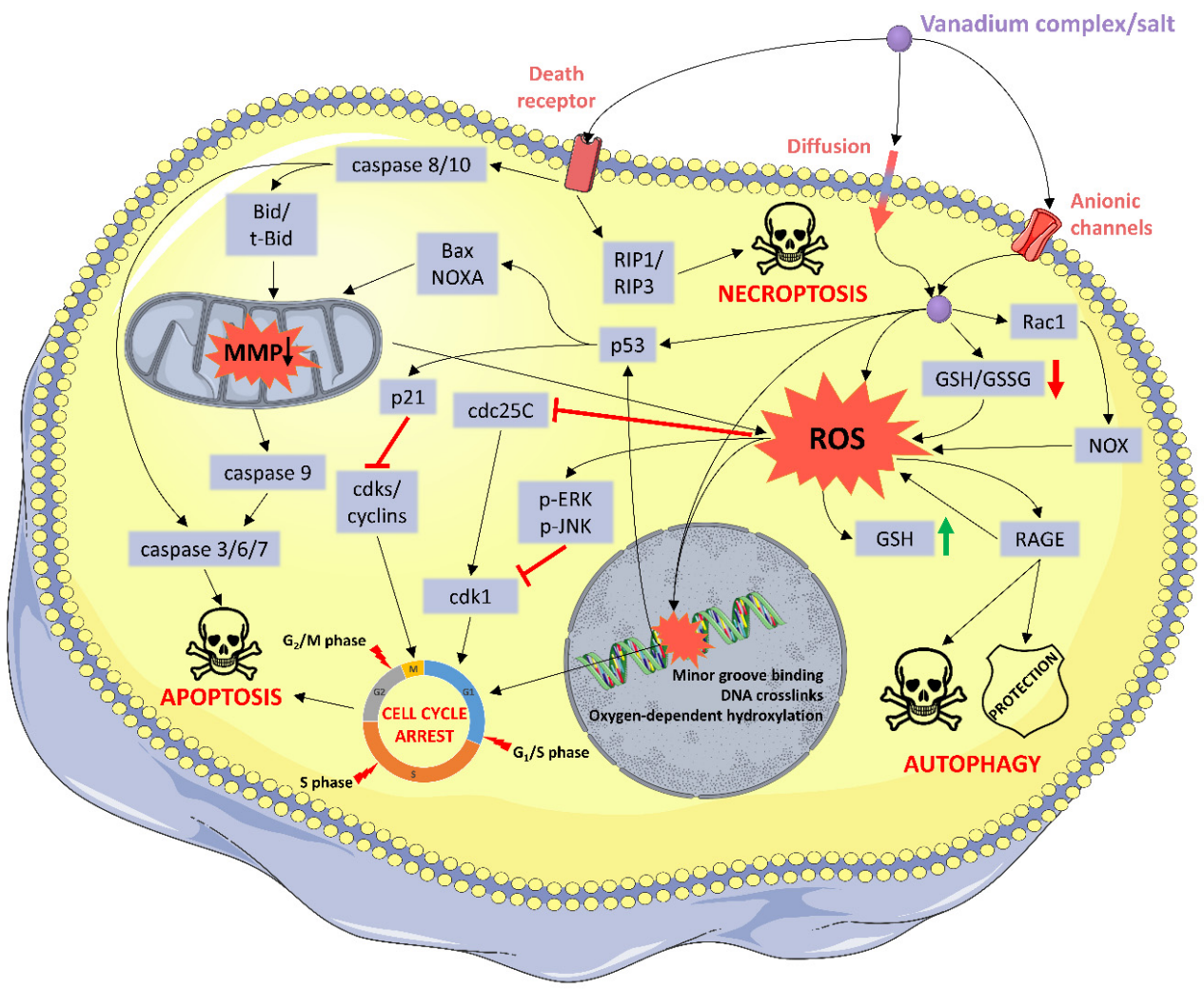

Figure 2. Summary of the suggested molecular and cellular mechanisms of vanadium compounds. ROS: reactive oxygen species; MMP: mitochondrial membrane potential; GSH: reduced glutathione; GSSG: oxidized glutathione; NOX: NADPH oxidase. Elements of this illustration were provided by Servier Medical Art (http://smart.servier.com/). 


\subsection{Other Mechanims}

Many other mechanisms in the anticancer activity of vanadium compounds have been determined which are described in other reviews.

Kioseoglou et al. [20] described impacts on cell metabolism. For example, the level of mRNA of key metabolicglycolytic enzymes in the liver, including phosphoenolpyruvate carboxykinase (PEPCK), glucokinase (GK), and L-pyruvate kinase (L-PK), were significantly restored toward normal values in diabetic animals treated with vanadium compounds [103]. Moreover, sodium vanadate affected the activity of pulmonary 6-phosphogluconate dehydrogenase (6PGDH), pyruvate kinase (PK) and glutathione peroxidase (GP), and in higher doses lactate dehydrogenase (LDH) and glutathione reductase (GR) [104]. Because cancer cells exhibit drastically enhanced glucose uptake and glycolysis (the Warburg effect), vanadium-based compounds could be an interesting treatment option [20]. In the same review, the molecular mechanism of the epithelial-mesenchymal transition (EMT) inhibition by vanadium was described [20]. EMT is a process during which epithelial cells lose their polarized organization and cell-to-cell adhesion and undergo changes in cell shape and cytoskeletal organization, which ultimately lead to cell migration and invasion [20].

Irving and et al. [105] discussed the potential of vanadium derivatives as protein tyrosine phosphatases (PTP) enzyme inhibitors. Phosphotyrosine signaling is implicated in almost all aspects of cancer biology due to its widespread influence over cell signaling, and alterations brought about by mutations can drive the initiation and progression of many different tumor types [106]. It has been determined that various vanadium compounds were shown to be successful in inhibiting tumor development in animal models through their ability to inhibit PTPs and to induce oxidative damage, which itself likely contributes to PTP inhibition [105].

Interestingly, both pro- and anti-inflammatory effects have been documented for V-containing compounds [107]. The immunomodulatory activity of vanadium compounds includes effects on $\mathrm{T}$ cell, B cell and NK cell activity as well as effects on the level of proinflammatory cytokines and mediators such as NF-кB, COX-2 or IL-6 [107]. For instance, $\mathrm{NH}_{4} \mathrm{VO}_{3}$ was exhibited to prevent T cell activation by downregulating the expression of proinflammatory cytokines including IL-2, IL-6, TNF- $\alpha$, and IFN- $\gamma$ [108]. Triggering Toll-like receptors (TLR) to generate an immune response is considered to be another mechanism through which vanadium compounds could regulate immune response [107].

Furthermore, in addition to potential anticancer activity, vanadium compounds exhibit a well-established antidiabetic activity [109]. Vanadate binds to the active side of PTP-1B (which counteracts the insulin receptor (IR) in the absence of insulin or in the insufficient insulin response), due to its similarity to phosphate, and inhibits it. Consequently, signal transduction paths for glucose uptake are restored [109].

\section{Conclusions}

The studies described in this review suggest that the molecular and cellular mechanisms of vanadium compounds depend on many factors, including the oxidation state of the vanadium cation, organic ligands, spatial structure and also the type of cancer cell lines. That is why we can observe so many, sometimes mutually exclusive, mechanisms of cytotoxicity.

The literature review revealed that the chemical form of vanadium-based complexes (oxidation state of vanadium, the type of the ligands and their geometrical arrangement) influences their physicochemical properties and thus their biological properties. For instance, the presence of a strong binding ligand in the coordination sphere of the $\mathrm{VO}^{2+}$ ion hinders oxidation of the metal ion, V(IV) to V(V) [110]. Furthermore, nuclease activity of the V-phenanthroline, V-bipyridine and V-terpyridine compounds depends on the number of intercalating heterocyclic moieties. It suggests that the incorporation into the coordination sphere of the vanadium cation of the appropriate type of ligands may promote redox reactions or enhance the interaction with nucleic acids. This leads to oxidative stress, DNA damage, cell cycle arrest and ultimately to cell death (Figure 2). 
Although there is some evidence that the structure and physicochemical properties of vanadium complexes impact their biological activity, the correlation of the chemical form of vanadium-based complexes versus their mechanism of action still remains to be elucidated. Moreover, the differences in physicochemical and biological properties of the compounds may stem from very different experimental (chemical and biological) conditions. The results of chemical studies on physicochemical properties of the compounds should be assessed very carefully as the experimental conditions leading to these results are generally very different from biological conditions. Furthermore, there are still very few in vivo studies and an almost complete lack of innovative approaches based on targeted therapies. In view of this, further biological research, focusing on a more in-depth analysis of cytotoxic activity using the most modern techniques, is required.

In conclusion, the above considerations underline the anticancer potential of vanadium-based compounds. Through modification of the chemical form of vanadium-based complexes, we can influence affinity for DNA, oxidative stress or the type of cell death induced by vanadium-based compounds in cancer cells. On the other hand, due to many factors, it is difficult to precisely define structure-activity relationships.

Author Contributions: Conceptualization, I.I.-S. and S.K.; writing, original draft preparation, S.K.; writing, review and editing, I.I.-S. and D.W.; visualization, S.K. and D.W.; supervision, I.I.-S.; project administration, I.I.-S.; funding acquisition, I.I.-S., S.K. All authors have read and agreed to the published version of the manuscript.

Funding: This work was supported by the St-46 from the Medical University of Gdansk, Poland.

Conflicts of Interest: The authors declare no conflict of interest.

\section{Glossary}

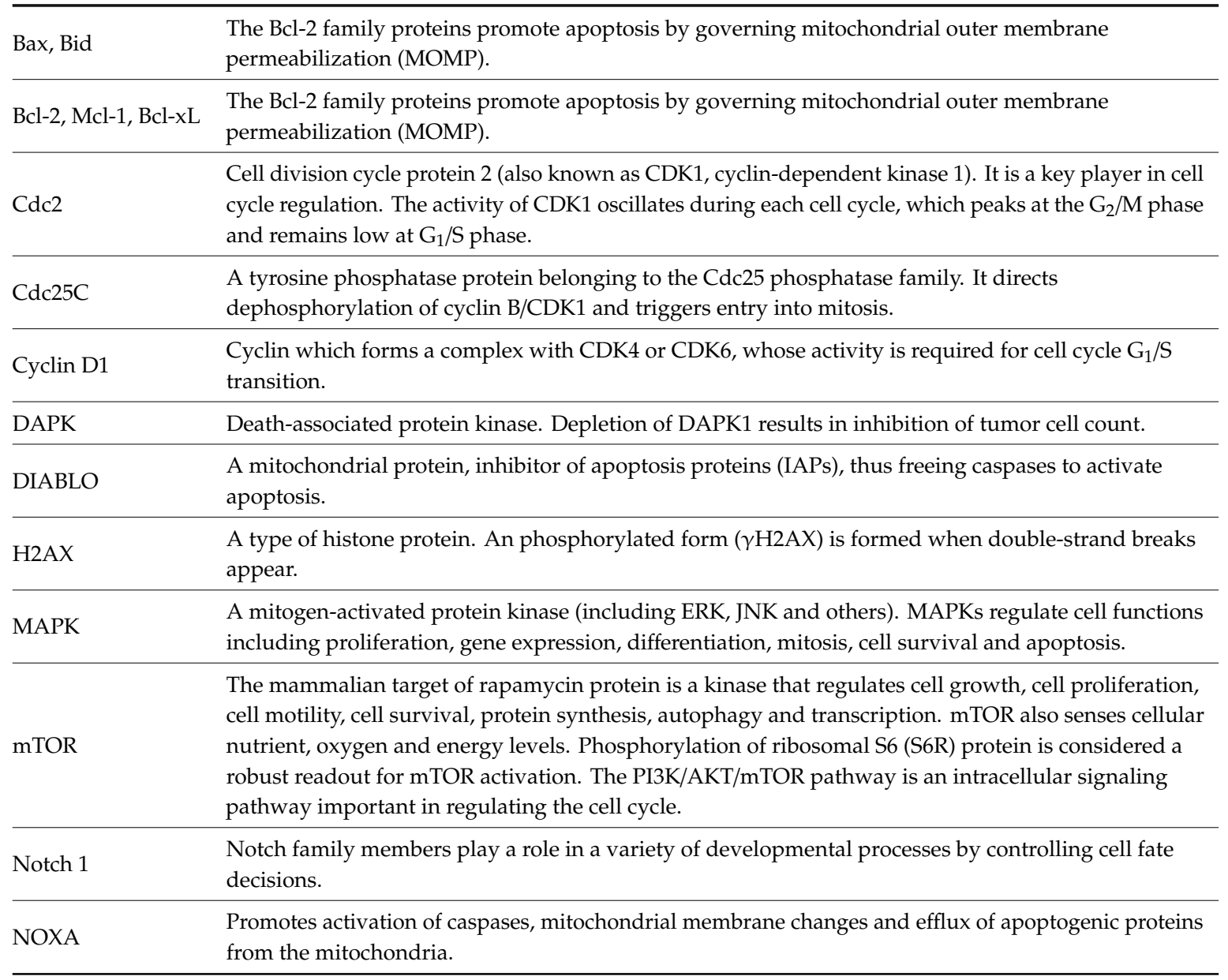




\begin{tabular}{|c|c|}
\hline p21 & $\begin{array}{l}\text { Cyclin-dependent kinase inhibitor } 1 \text {. It represents a major target of p53 activity and thus is associated } \\
\text { with linking DNA damage to cell cycle arrest. }\end{array}$ \\
\hline p53 & $\begin{array}{l}\text { Protein plays a role in regulation or progression through the cell cycle, apoptosis, and genomic } \\
\text { stability. }\end{array}$ \\
\hline PARP & $\begin{array}{l}\text { Poly (ADP-ribose) polymerase is involved in a number of cellular processes such as DNA repair, } \\
\text { genomic stability, and programed cell death. }\end{array}$ \\
\hline PI3K & $\begin{array}{l}\text { Phosphoinositide 3-kinases. a family of enzymes involved in cellular functions such as cell growth, } \\
\text { proliferation, differentiation, motility, survival. The PI3K/AKT/mTOR pathway is an intracellular } \\
\text { signalling pathway important in regulating the cell cycle. }\end{array}$ \\
\hline PKB/Akt & $\begin{array}{l}\text { Protein kinase B (PKB or Akt) plays a key role in multiple cellular processes such as glucose } \\
\text { metabolism, apoptosis, cell proliferation, transcription, and cell migration. Activation of PKB was } \\
\text { shown to overcome cell cycle arrest in G1 and G2 phases. }\end{array}$ \\
\hline Rac-1 & $\begin{array}{l}\text { Small signaling G proteins which are pleiotropic regulators of many cellular processes, including the } \\
\text { cell cycle, cell-cell adhesion, motility. Rac- } 1 \text { activates NADPH oxidase inducing ROS generation. }\end{array}$ \\
\hline RAGE & $\begin{array}{l}\text { Receptor for advanced glycation end products. Overexpression of RAGE in pancreatic cancer cells is } \\
\text { associated with enhanced autophagy, diminished apoptosis and greater tumor cell viability. }\end{array}$ \\
\hline $\mathrm{Rb}$ & $\begin{array}{l}\text { The retinoblastoma protein prevents excessive cell growth by inhibiting cell cycle progression until a } \\
\text { cell is ready to divide. } \mathrm{Rb} \text { is phosphorylated to } \mathrm{pRb} \text { leading to the inactivation of the activity of } \\
\text { Retinoblastoma protein. It allows cells to enter into the cell cycle state. } \mathrm{Rb} \text { is dysfunctional in many } \\
\text { cancers. }\end{array}$ \\
\hline RET/PTC1 & The most prevalent type of gene rearrangement found in papillary thyroid carcinoma. \\
\hline VEGF & $\begin{array}{l}\text { Vascular endothelial growth factor is a signal protein produced by cells that stimulates the formation } \\
\text { of blood vessels. }\end{array}$ \\
\hline
\end{tabular}

\section{References}

1. Bradford, S.S.; Cowan, J.A. From traditional drug design to catalytic metallodrugs: A brief history of the use of metals in medicine. Metallodrugs 2014, 1. [CrossRef]

2. Elledge, S.J.; Zhou, Z.; Allen, J.B. Ribonucleotide reductase: Regulation, regulation, regulation. Trends Biochem. Sci. 1992, 17, 119-123. [CrossRef]

3. Parisi, A.F.; Vallee, B.L. Zinc metalloenzymes: Characteristics and significance in biology and medicine. Am. J. Clin. Nutr. 1969, 22, 1222-1239. [CrossRef] [PubMed]

4. Rosenberg, B.; Van Camp, L.; Krigas, T. Inhibition of cell division in escherichia coli by electrolysis products from a platinum electrode. Nature 1965, 698-699. [CrossRef] [PubMed]

5. Prestayko, A.W.; D’Aoust, J.C.; Issell, B.F.; Crooke, S.T. Cisplatin (Cis-Diamminedichloroplatinum II). Cancer Treat. Rev. 1979, 6, 17-39. [CrossRef]

6. Cleare, M.J.; Hoeschele, J.D. Studies on the antitumor activity of group VIII transition metal complexes. Part I. Platinum (II) complexes. Bioinorg. Chem. 1973, 2, 187-210. [CrossRef]

7. Kidani, Y.; Noji, M.; Tashiro, T. Antitumor activity of Platinum(II) complexes of 1,2-Diamino-Cyclohexane isomers. Gann Jpn. J. Cancer Res. 1980, 71, 637-643. [CrossRef]

8. Sharma, H.; Thatcher, N.; Baer, J.; Zaki, A.; Smith, A.; McAucliffe, C.A.; Crowther, D.; Owens, S.; Fox, B.W. Blood clearance of radioactively labelled Cis-Diammine 1,1-Cyclobutane Dicarboxylate Platinum(II) (CBDCA) in cancer patients. Cancer Chemother. Pharmacol. 1983, 11, 5-7. [CrossRef]

9. Tashiro, T.; Kawada, Y.; Sakurai, Y.; Kidani, Y. Antitumor activity of a new platinum complex, oxalato (Trans-1-1,2-Diaminocyclohexane)Platinum (II): New experimental data. Biomed. Pharmacother. 1989, 43, 251-260. [CrossRef]

10. Hayes, D.M.; Cvitkovic, E.; Golbey, R.B.; Scheiner, E.; Helson, L.; Krakoff, I.H. High dose cis-platinum diammine dichloride: Amelioration of renal toxicity by mannitol diuresis. Cancer 1977, 39, 1372-1381. [CrossRef]

11. Safirstein, R.; Winston, J.; Goldstein, M.; Moel, D.; Dikman, S.; Guttenplan, J. Cisplatin nephrotoxicity. Am. J. Kidney Dis. 1986, 8, 356-367. [CrossRef]

12. Komeda, S.; Casini, A. Next-generation anticancer Metallodrugs. Curr. Top. Med. Chem. 2012, 12, $219-235$. [CrossRef] [PubMed] 
13. Bruijnincx, P.C.; Sadler, P.J. New trends for metal complexes with anticancer activity. Curr. Opin. Chem. Biol. 2008, 197-206. [CrossRef] [PubMed]

14. Waters, E.A.; Wickline, S.A. Contrast agents for MRI. Basic Res. Cardiol. 2008, 114-121. [CrossRef]

15. Price, T.W.; Greenman, J.; Stasiuk, G.J. Current advances in ligand design for inorganic positron emission tomography tracers $68 \mathrm{Ga}, 64 \mathrm{Cu}, 89 \mathrm{Zr}$ and 44 Sc. Dalton Trans. 2016, 45, 15702-15724. [CrossRef]

16. Feng, L.; Geisselbrecht, Y.; Blanck, S.; Wilbuer, A.; Atilla-Gokcumen, G.E.; Filippakopoulos, P.; Kräling, K.; Celik, M.A.; Harms, K.; Maksimoska, J.; et al. Structurally sophisticated octahedral metal complexes as highly selective protein kinase inhibitors. J. Am. Chem. Soc. 2011, 133, 5976-5986. [CrossRef]

17. Rehder, D. The role of vanadium in biology. Metallomics 2015, 7, 730-742. [CrossRef]

18. Anke, M. Spurenelement Symposium: New Trace Elements; Anke, M., Baumann, W., Braunlich, H., Bruckner, C., Groppel, B., Eds.; FriedrichSchiller-Universitat: Jena, Germany, 1986; pp. 1266-1275.

19. Pessoa, J.C.; Etcheverry, S.; Gambino, D. Vanadium compounds in medicine. Coord. Chem. Rev. 2015, 301-302, 24-48. [CrossRef]

20. Kioseoglou, E.; Petanidis, S.; Gabriel, C.; Salifoglou, A. The chemistry and biology of vanadium compounds in cancer therapeutics. Coord. Chem. Rev. 2015, 301, 87-105. [CrossRef]

21. Leon, E.I.; Cadavid-Vargas, F.J.; Di Virgilio, L.A.; Etcheverry, B.S. Vanadium, ruthenium and copper compounds: A new class of nonplatinum metallodrugs with anticancer activity. Curr. Med. Chem. 2017, 24, 112-148. [CrossRef]

22. Rehder, D. Implications of vanadium in technical applications and pharmaceutical issues. Inorg. Chim. Acta 2017, 455, 378-389. [CrossRef]

23. Fuertes, M.; Castilla, J.; Alonso, C.; Pérez, J. Cisplatin biochemical mechanism of action: From cytotoxicity to induction of cell death through interconnections between apoptotic and necrotic pathways. Curr. Med. Chem. 2012, 10, 257-266. [CrossRef] [PubMed]

24. Anastassopoulou, J. Metal-DNA interactions. J. Mol. Struct. 2003, 651-653, 19-26. [CrossRef]

25. Mohamadi, M.; Yousef Ebrahimipour, S.; Torkzadeh-Mahani, M.; Foro, S.; Akbari, A. A mononuclear Diketone-based Oxido-Vanadium(IV) complex: Structure, DNA and BSA binding, molecular docking and anticancer ActIVities against MCF-7, HPG-2, and HT-29 cell lines. RSC Adv. 2015, 5, 101063-101075. [CrossRef]

26. Inamdar, P.R.; Sheela, A. Exploration of DNA binding mode, chemical nuclease, cytotoxic and apoptotic potentials of diketone based Oxovanadium(IV) complexes. Int. J. Biol. Macromol. 2015, 76, 269-278. [CrossRef] [PubMed]

27. Dankhoff, K.; Ahmad, A.; Weber, B.; Biersack, B.; Schobert, R. Anticancer properties of a new Non-Oxido Vanadium(IV) complex with a catechol-modified 3,3'-Diindolylmethane ligand. J. Inorg. Biochem. 2019, 194, 1-6. [CrossRef] [PubMed]

28. Fik, M.A.; Gorczyński, A.; Kubicki, M.; Hnatejko, Z.; Wadas, A.; Kulesza, P.J.; Lewińska, A.; Giel-Pietraszuk, M.; Wyszko, E.; Patroniak, V. New vanadium complexes with 6,6"-Dimethyl-2,2':6' ,2"-Terpyridine in terms of structure and biological properties. Polyhedron 2015, 97, 83-93. [CrossRef]

29. Correia, I.; Roy, S.; Matos, C.P.; Borovic, S.; Butenko, N.; Cavaco, I.; Marques, F.; Lorenzo, J.; Rodríguez, A.; Moreno, V.; et al. Vanadium(IV) and Copper(II) complexes of salicylaldimines and aromatic heterocycles: Cytotoxicity, DNA binding and DNA cleavage properties. J. Inorg. Biochem. 2015, 147, 134-146. [CrossRef]

30. Rui, W.; Tian, X.; Zeng, P.; Liu, W.; Ying, P.; Chen, H.; Lu, J.; Yang, N.; Chen, H. The anti-tumor activity of novel Oxovanadium complexes derived from Thiosemicarbazones and Fluoro-phenanthroline derivatives. Polyhedron 2016, 117, 803-816. [CrossRef]

31. Bai, Y.L.; Zhang, Y.W.; Xiao, J.Y.; Guo, H.W.; Liao, X.W.; Li, W.J.; Zhang, Y.C. Oxovanadium Phenanthroimidazole derivatives: Synthesis, DNA binding and antitumor activities. Transit. Met. Chem. 2018, 43, 171-183. [CrossRef]

32. Mal, S.K.; Chattopadhyay, T.; Fathima, A.; Purohit, C.S.; Kiran, M.S.; Nair, B.U.; Ghosh, R. Synthesis and structural characterization of a Vanadium(V)-Pyridylbenzimidazole complex: DNA binding and anticancer activity. Polyhedron 2017, 126, 23-27. [CrossRef]

33. Patra, D.; Paul, S.; Sepay, N.; Kundu, R.; Ghosh, T. Structure-activity relationship on DNA binding and anticancer activities of a family of mixed-ligand Oxidovanadium $(\mathrm{V})$ hydrazone complexes. J. Biomol. Struct. Dyn. 2018, 36, 4143-4155. [CrossRef] [PubMed] 
34. Al-Hazmi, G.A.; Abou-Melha, K.S.; El-Metwaly, N.M.; Saleh, K.A. Synthesis of novel VO(II)-Perimidine complexes: Spectral, computational, and antitumor studies. Bioinorg. Chem. Appl. 2018, 2018. [CrossRef] [PubMed]

35. Agostinis, P.; Berg, K.; Cengel, K.A.; Foster, T.H.; Girotti, A.W.; Gollnick, S.O.; Hahn, S.M.; Hamblin, M.R.; Juzeniene, A.; Kessel, D.; et al. Photodynamic therapy of cancer: An update. CA Cancer J. Clin. 2011, 61, 250-281. [CrossRef] [PubMed]

36. Kumar, A.; Dixit, A.; Banerjee, S.; Bhattacharyya, A.; Garai, A.; Karande, A.A.; Chakravarty, A.R. Cellular imaging and mitochondria targeted photo-cytotoxicity in visible light by singlet oxygen using a BODIPY-appended Oxovanadium(IV) DNA crosslinking agent. Medchemcomm 2016, 7, 1398-1404. [CrossRef]

37. Kumar, A.; Pant, I.; Dixit, A.; Banerjee, S.; Banik, B.; Saha, R.; Kondaiah, P.; Chakravarty, A.R. Terpyridyl Oxovanadium(IV) complexes for DNA crosslinking and Mito-targeted Photocytotoxicity. J. Inorg. Biochem. 2017, 174, 45-54. [CrossRef]

38. Dash, S.P.; Panda, A.K.; Pasayat, S.; Dinda, R.; Biswas, A.; Tiekink, E.R.T.; Mukhopadhyay, S.; Bhutia, S.K.; Kaminsky, W.; Sinn, E. Oxidovanadium(v) complexes of Aroylhydrazones incorporating heterocycles: Synthesis, characterization and study of DNA binding, photo-induced DNA cleavage and cytotoxic activities. RSC Adv. 2015, 5, 51852-51867. [CrossRef]

39. Champoux, J.J. DNA topoisomerases: Structure, function, and mechanism. Annu. Rev. Biochem. 2001, 70, 369-413. [CrossRef]

40. León, I.E.; Cadavid-Vargas, J.F.; Tiscornia, I.; Porro, V.; Castelli, S.; Katkar, P.; Desideri, A.; Bollati-Fogolin, M.; Etcheverry, S.B. Oxidovanadium(IV) complexes with Chrysin and Silibinin: Anticancer activity and mechanisms of action in a human colon adenocarcinoma model. JBIC J. Biol. Inorg. Chem. 2015, 20, 1175-1191. [CrossRef]

41. Sies, H.; Berndt, C.; Jones, D.P. Oxidative stress. Annu. Rev. Biochem. 2017, 86, 715-748. [CrossRef]

42. Sies, H.; Sies, H. Oxidative stress: Introductory remarks. N. Y. Acad. J. 1985, 5, 1-8.

43. Sies, H.; Jones, D. Oxidative stress. In Encyclopedia of Stress; Elsevier Inc.: Amsterdam, The Netherlands, 2007; pp. 45-48. [CrossRef]

44. Irshad, M.; Chaudhuri, P.S. Oxidant-Antioxidant System: Role and Significance in Human Body; NISCAIR-CSIR: New Delhi, India, 2002; Volume 40, pp. 1233-1239.

45. Sosa, V.; Moliné, T.; Somoza, R.; Paciucci, R.; Kondoh, H.; LLeonart, M.E. Oxidative stress and cancer: An overview. Ageing Res. Rev. 2013, 376-390. [CrossRef] [PubMed]

46. Guerrero-Palomo, G.; Rendón-Huerta, E.P.; Montaño, L.F.; Fortoul, T.I. Vanadium compounds and cellular death mechanisms in the A549 cell line: The relevance of the compound valence. J. Appl. Toxicol. 2019, 39, 540-552. [CrossRef] [PubMed]

47. Chatterjee, N.; Anwar, T.; Islam, N.S.; Ramasarma, T.; Ramakrishna, G. Growth arrest of lung carcinoma cells (A549) by Polyacrylate-anchored Peroxovanadate by activating Rac1-NADPH oxidase signalling axis. Mol. Cell. Biochem. 2016, 420, 9-20. [CrossRef]

48. Sinha, A.; Banerjee, K.; Banerjee, A.; Sarkar, A.; Ahir, M.; Adhikary, A.; Chatterjee, M.; Choudhuri, S.K. Induction of apoptosis in human colorectal cancer cell line, HCT-116 by a vanadium- schiff base complex. Biomed. Pharmacother. 2017, 92, 509-518. [CrossRef]

49. Wu, J.-X.; Hong, Y.-H.; Yang, X.-G. Bis(Acetylacetonato)-Oxidovanadium(IV) and sodium metavanadate inhibit cell proliferation via ROS-induced sustained MAPK/ERK activation but with elevated AKT activity in human pancreatic cancer AsPC-1 cells. JBIC J. Biol. Inorg. Chem. 2016, 21, 919-929. [CrossRef]

50. Molinuevo, M.S.; Barrio, D.A.; Cortizo, A.M.; Etcheverry, S.B. Antitumoral properties of two new Vanadyl(IV) complexes in osteoblasts in culture: Role of apoptosis and oxidative stress. Cancer Chemother. Pharmacol. 2004, 53, 163-172. [CrossRef]

51. León, I.E.; Butenko, N.; Di Virgilio, A.L.; Muglia, C.I.; Baran, E.J.; Cavaco, I.; Etcheverry, S.B. Vanadium and cancer treatment: Antitumoral mechanisms of three Oxidovanadium(IV) complexes on a human osteosarcoma cell line. J. Inorg. Biochem. 2014, 134, 106-117. [CrossRef]

52. Kowalski, S.; Hać, S.; Wyrzykowski, D.; Zauszkiewicz-Pawlak, A.; Inkielewicz-Stępniak, I. Selective cytotoxicity of vanadium complexes on human pancreatic ductal adenocarcinoma cell line by inducing necroptosis, apoptosis and mitotic catastrophe process. Oncotarget 2017, 8, 60324-60341. [CrossRef] 
53. De Cunha Padua, M.M.; Suter Correia Cadena, S.M.; de Oliveira Petkowicz, C.L.; Martinez, G.R.; Merlin Rocha, M.E.; Mercê, A.L.R.; Noleto, G.R. Toxicity of native and Oxovanadium (IV/V) galactomannan complexes on HepG2 cells is related to impairment of mitochondrial functions. Carbohydr. Polym. 2017, 173, 665-675. [CrossRef]

54. Li, J.; Jiang, M.; Zhou, H.; Jin, P.; Cheung, K.M.C.; Chu, P.K.; Yeung, K.W.K. Vanadium dioxide nanocoating induces tumor cell death through mitochondrial electron transport chain interruption. Glob. Chall. 2019, 3, 1800058. [CrossRef] [PubMed]

55. Wang, Q.; Liu, T.T.; Fu, Y.; Wang, K.; Yang, X.G. Vanadium compounds discriminate hepatoma and normal hepatic cells by differential regulation of reactive oxygen species. J. Biol. Inorg. Chem. 2010, 15, 1087-1097. [CrossRef] [PubMed]

56. Naso, L.G.; Valcarcel, M.; Roura-Ferrer, M.; Kortazar, D.; Salado, C.; Lezama, L.; Rojo, T.; González-Baró, A.C.; Williams, P.A.M.; Ferrer, E.G. Promising antioxidant and anticancer (human breast cancer) Oxidovanadium(IV) complex of chlorogenic acid. synthesis, characterization and spectroscopic examination on the transport mechanism with bovine serum albumin. J. Inorg. Biochem. 2014, 135, 86-99. [CrossRef] [PubMed]

57. Torel, J.; Cillard, J.; Cillard, P. Antioxidant activity of flavonoids and reactivity with peroxy radical. Phytochemistry 1986, 25, 383-385. [CrossRef]

58. Huyut, Z.; Beydemir, Ş.; Gülçin, I. Antioxidant and antiradical properties of selected flavonoids and phenolic compounds. Biochem. Res. Int. 2017, 2017. [CrossRef] [PubMed]

59. Naso, L.G.; Lezama, L.; Rojo, T.; Etcheverry, S.B.; Valcarcel, M.; Roura, M.; Salado, C.; Ferrer, E.G.; Williams, P.A.M. Biological evaluation of morin and its new Oxovanadium(IV) complex as antio-xidant and specific anti-cancer agents. Chem. Biol. Interact. 2013, 206, 289-301. [CrossRef] [PubMed]

60. Martínez Medina, J.J.; Naso, L.G.; Pérez, A.L.; Rizzi, A.; Okulik, N.B.; Ferrer, E.G.; Williams, P.A.M. Apigenin Oxidovanadium(IV) cation interactions. Synthesis, spectral, bovine serum albumin binding, antioxidant and anticancer studies. J. Photochem. Photobiol. A Chem. 2017, 344, 84-100. [CrossRef]

61. Leon, I.E.; Di Virgilio, A.L.; Porro, V.; Muglia, C.I.; Naso, L.G.; Williams, P.A.M.; Bollati-Fogolin, M.; Etcheverry, S.B. Antitumor properties of a Vanadyl(Iv) complex with the flavonoid chrysin [VO(Chrysin)2EtOH]2 in a human osteosarcoma model: The role of oxidative stress and apoptosis. Dalton Trans. 2013, 42, 11868. [CrossRef]

62. Martínez Medina, J.J.; Naso, L.G.; Pérez, A.L.; Rizzi, A.; Ferrer, E.G.; Williams, P.A.M. Antioxidant and anticancer effects and bioavailability studies of the flavonoid baicalin and its Oxidovanadium(IV) complex. J. Inorg. Biochem. 2017, 166, 150-161. [CrossRef]

63. Basu, A.; Bhattacharjee, A.; Hajra, S.; Samanta, A.; Bhattacharya, S. Ameliorative effect of an Oxovanadium (IV) complex against oxidative stress and nephrotoxicity induced by Cisplatin. Redox Rep. 2017, 22, 377-387. [CrossRef]

64. Basu, A.; Bhattacharjee, A.; Samanta, A.; Bhattacharya, S. Prevention of cyclophosphamide-induced hepatotoxicity and genotoxicity: Effect of an 1-Cysteine based Oxovanadium(IV) complex on oxidative stress and DNA damage. Environ. Toxicol. Pharmacol. 2015, 40, 747-757. [CrossRef] [PubMed]

65. Balaji, B.; Balakrishnan, B.; Perumalla, S.; Karande, A.A.; Chakravarty, A.R. Photocytotoxic Oxovanadium(IV) complexes of Ferrocenyl-Terpyridine and Acetylacetonate derivatives. Eur. J. Med. Chem. 2015, 92, 332-341. [CrossRef] [PubMed]

66. Shi, X.; Jiang, H.; Mao, Y.; Ye, J.; Saffiotti, U. Vanadium(IV)-mediated free radical generation and related 2'-Deoxyguanosine hydroxylation and DNA damage. Toxicology 1996, 106, 27-38. [CrossRef]

67. Williams, G.H.; Stoeber, K. The cell cycle and cancer. J. Pathol. 2012, 226, 352-364. [CrossRef]

68. Pietenpol, J.A.; Stewart, Z.A. Cell cycle checkpoint signaling: Cell cycle arrest versus apoptosis. Toxicology 2002, 181-182, 475-481. [CrossRef]

69. Xiong, Y. Why are there so many CDK inhibitors? Biochim. Biophys. Acta 1996. [CrossRef]

70. Bunz, F.; Dutriaux, A.; Lengauer, C.; Waldman, T.; Zhou, S.; Brown, J.P.; Sedivy, J.M.; Kinzler, K.W.; Vogelstein, B. Requirement for P53 and P21 to sustain G2 arrest after DNA damage. Science 1998, 282, 1497-1501. [CrossRef]

71. Flatt, P.M.; Tang, L.J.; Scatena, C.D.; Szak, S.T.; Pietenpol, J.A. P53 regulation of G2 checkpoint is retinoblastoma protein dependent. Mol. Cell. Biol. 2000, 20, 4210-4223. [CrossRef]

72. Nilsson, I.; Hoffmann, I. Cell cycle regulation by the Cdc25 phosphatase family. Prog. Cell Cycle Res. 2000, 107-114. [CrossRef] 
73. Desoize, B. Metals and metal compounds in cancer treatment. Anticancer Res. 2004, 24, 1529-1544.

74. Liu, T.T.; Liu, Y.J.; Wang, Q.; Yang, X.G.; Wang, K. Reactive-oxygen-species-mediated Cdc25C degradation results in differential antiproliferative activities of vanadate, tungstate, and Molybdate in the PC-3 human prostate cancer cell line. J. Biol. Inorg. Chem. 2012, 17, 311-320. [CrossRef] [PubMed]

75. Yu, Q.; Jiang, W.; Li, D.; Gu, M.; Liu, K.; Dong, L.; Wang, C.; Jiang, H.; Dai, W. Sodium Orthovanadate inhibits growth and triggers apoptosis of human anaplastic thyroid carcinoma cells in vitro and in vivo. Oncol. Lett. 2019, 17, 4255-4262. [CrossRef] [PubMed]

76. Gonçalves, A.P.; Videira, A.; Soares, P.; Máximo, V. Orthovanadate-induced cell death in RET/PTC1-harboring cancer cells involves the activation of caspases and altered signaling through PI3K/Akt/MTOR. Life Sci. 2011, 89, 371-377. [CrossRef] [PubMed]

77. Rozzo, C.; Sanna, D.; Garribba, E.; Serra, M.; Cantara, A.; Palmieri, G.; Pisano, M. Antitumoral effect of vanadium compounds in malignant melanoma cell lines. J. Inorg. Biochem. 2017, 174, 14-24. [CrossRef]

78. Pisano, M.; Arru, C.; Serra, M.; Galleri, G.; Sanna, D.; Garribba, E.; Palmieri, G.; Rozzo, C. Antiproliferative activity of vanadium compounds: Effects on the major malignant melanoma molecular pathways. Metallomics 2019, 11, 1687-1699. [CrossRef]

79. Kowalski, S.; Wyrzykowski, D.; Hac, S.; Rychlowski, M.; Radomski, M.W.; Inkielewicz-Stepniak, I.; Kowalski, S.; Wyrzykowski, D.; Hac, S.; Rychlowski, M.; et al. New Oxidovanadium(IV) coordination complex containing 2-Methylnitrilotriacetate ligands induces cell cycle arrest and autophagy in human pancreatic ductal adenocarcinoma cell lines. Int. J. Mol. Sci. 2019, 20, 261. [CrossRef]

80. Nair, R.S.; Kuriakose, M.; Somasundaram, V.; Shenoi, V.; Kurup, M.R.P.; Srinivas, P. The molecular response of vanadium complexes of Nicotinoyl Hydrazone in cervical cancers-A possible interference with HPV oncogenic markers. Life Sci. 2014, 116, 90-97. [CrossRef]

81. Ni, L.; Zhao, H.; Tao, L.; Li, X.; Zhou, Z.; Sun, Y.; Chen, C.; Wei, D.; Liu, Y.; Diao, G. Synthesis, in vitro cytotoxicity, and structure-ActIVity relationships (SAR) of Multidentate Oxidovanadium(IV) complexes as anticancer agents. Dalton Trans. 2018, 47, 10035-10045. [CrossRef]

82. Zhang, Y.L.; Wang, X.S.; Fang, W.; Cai, X.Y.; Li, H.Z.; Mao, J.W.; Jin, X.B.; Bai, Y.L.; Lu, J.Z. In vitro study of the Cytotoxicities of two mixed-ligand Oxovanadium complexes on human Hepatoma cells. Pharmazie 2013, 68, 827-834. [CrossRef]

83. Ying, P.; Zeng, P.; Lu, J.; Chen, H.; Liao, X.; Yang, N. New Oxidovanadium complexes incorporating Thiosemicarbazones and 1, 10-Phenanthroline derivatives as DNA cleavage, potential anticancer agents, and hydroxyl radical scavenger. Chem. Biol. Drug Des. 2015, 86, 926-937. [CrossRef]

84. Yang, J.; Zhang, Z.; Jiang, S.; Zhang, M.; Lu, J.; Huang, L.; Zhang, T.; Gong, K.; Yan, S.; Yang, Z.; et al. Vanadate-induced antiproliferative and apoptotic response in esophageal squamous carcinoma cell line EC109. J. Toxicol. Environ. Health 2016, 79, 864-868. [CrossRef] [PubMed]

85. Reytman, L.; Hochman, J.; Tshuva, E.Y. Anticancer Diaminotris (Phenolato) Vanadium(V) complexes: Ligand-metal interplay. J. Coord. Chem. 2018, 71, 2003-2011. [CrossRef]

86. Zimmermann, K.C.; Green, D.R. How cells die: Apoptosis pathways. J. Allergy Clin. Immunol. 2001, 108, S99-S103. [CrossRef] [PubMed]

87. Hassan, M.; Watari, H.; Abualmaaty, A.; Ohba, Y.; Sakuragi, N. Apoptosis and molecular targeting therapy in cancer. Biomed. Res. Int. 2014. [CrossRef] [PubMed]

88. Khalil, A.A.; Jameson, M.J. Sodium orthovanadate inhibits proliferation and triggers apoptosis in oral squamous cell carcinoma in vitro. Biochemistry 2017, 82, 149-155. [CrossRef] [PubMed]

89. Lu, L.P.; Suo, F.Z.; Feng, Y.L.; Song, L.L.; Li, Y.; Li, Y.J.; Wang, K.T. Synthesis and biological evaluation of vanadium complexes as novel anti-tumor agents. Eur. J. Med. Chem. 2019, 176, 1-10. [CrossRef]

90. Roy, S.; Banerjee, S.; Chakraborty, T. Vanadium quercetin complex attenuates mammary cancer by regulating the P53, Akt/MTOR pathway and downregulates cellular proliferation correlated with increased apoptotic events. BioMetals 2018, 31, 647-671. [CrossRef]

91. Šebestová, L.; Havelek, R.; Řezáčová, M.; Honzíček, J.; Kročová, Z.; Vinklárek, J. Study of antitumor effect of selected vanadium and molybdenum organometallic complexes in human leukemic T-cells. Chem. Biol. Interact. 2015, 242, 61-70. [CrossRef]

92. Bakhshi Aliabad, H.; Khanamani Falahati-Pour, S.; Ahmadirad, H.; Mohamadi, M.; Hajizadeh, M.R.; Bakhshi, G.; Mahmoodi, M. Vanadium complex induced apoptosis in HepG2 cells by the up-regulation of p53, p21, and caspase-8. WCRJ 2019, 6, e1293. 
93. León, I.E.; Díez, P.; Baran, E.J.; Etcheverry, S.B.; Fuentes, M. Decoding the anticancer activity of VO-clioquinol compound: The mechanism of action and cell death pathways in human osteosarcoma cells. Metallomics 2017, 9, 891-901. [CrossRef]

94. Banerjee, S.; Dixit, A.; Shridharan, R.N.; Karande, A.A.; Chakravarty, A.R. Endoplasmic reticulum targeted chemotherapeutics: The remarkable photo-cytotoxicity of an Oxovanadium(IV) vitamin-B6 complex in visible light. Chem. Commun. 2014, 50, 5590-5592. [CrossRef] [PubMed]

95. Chandra, J.; Samali, A.; Orrenius, S. Triggering and modulation of apoptosis by oxidative stress. Free Radic. Biol. Med. 2000, 29, 323-333. [CrossRef]

96. Hanahan, D.; Weinberg, R.A. Hallmarks of cancer: The next generation. Cell 2011, 646-674. [CrossRef] [PubMed]

97. Kreuzaler, P.; Watson, C.J. Killing a cancer: What are the alternatives? Nat. Rev. Cancer 2012, 411-424. [CrossRef]

98. Christofferson, D.E.; Yuan, J. Necroptosis as an alternative form of programmed cell death. Curr. Opin. Cell Biol. 2010, 263-268. [CrossRef]

99. Shimizu, S.; Yoshida, T.; Tsujioka, M.; Arakawa, S. Autophagic cell death and cancer. Int. J. Mol. Sci. 2014, 15, 3145-3153. [CrossRef]

100. Rana, S.; McCaffrey, V.; Journal, B.R.-T.F. Vanadium complex induced cancer cell death via RIPK3 activated necroptosis. FASEB J. 2017, 31, 876.6.

101. El-Shafey, E.S.; Elsherbiny, E.S. Possible selective cytotoxicity of vanadium complex on breast cancer cells involving pathophysiological pathways. Anti Cancer Agents Med. Chem. 2019, 19, 2130-2139. [CrossRef]

102. Meyenberg Cunha-de Padua, M.; Noleto, G.R.; de Oliveira Petkowicz, C.L.; Cadena, S.M.S.C.; Bost, F.; Pouysségur, J.; Mazure, N.M. Hypoxia protects against the cell death triggered by Oxovanadium-Galactomannan complexes in HepG2 cells. Cell. Mol. Biol. Lett. 2019, 24, 18. [CrossRef]

103. Xie, M.; Chen, D.; Zhang, F.; Willsky, G.R.; Crans, D.C.; Ding, W. Effects of vanadium (III, IV, V)-chlorodipicolinate on glycolysis and antioxidant status in the liver of STZ-induced diabetic rats. J. Inorg. Biochem. 2014, 136, 47-56. [CrossRef]

104. Kacew, S.; Parulekar, M.R.; Merali, Z. Effects of parenteral vanadium administration on pulmonary metabolism of rats. Toxicol. Lett. 1982, 11, 119-124. [CrossRef]

105. Irving, E.; Stoker, A.W. Vanadium compounds as PTP inhibitors. Molecules 2017, 22, 2269. [CrossRef] [PubMed]

106. He, R.J.; Yu, Z.H.; Zhang, R.Y.; Zhang, Z.Y. Protein tyrosine phosphatases as potential therapeutic targets. Acta Pharmacol. Sin. 2014, 35, 1227-1246. [CrossRef] [PubMed]

107. Englinger, B.; Pirker, C.; Heffeter, P.; Terenzi, A.; Kowol, C.R.; Keppler, B.K.; Berger, W. Metal drugs and the anticancer immune response. Chem. Rev. 2018, 119, 1519-1624. [CrossRef]

108. Cohen, M.D.; Parsons, E.; Schlesinger, R.B.; Zelikoff, J.T. Immunotoxicity of in vitro vanadium exposures: Effects on interleukin-1, tumor necrosis factor- $\alpha$, and prostaglandin E2 production by WEHI-3 macrophages. Int. J. Immunopharmacol. 1993, 15, 437-446. [CrossRef]

109. Crans, D.C.; Henry, L.; Cardiff, G.; Posner, B.I. Developing vanadium as an antidiabetic or anticancer drug: A clinical and historical perspective. Met. Ions Life Sci. 2019, 203-230. [CrossRef]

110. Friedrich, A.; Hefele, H.; Mickler, W.; Mönner, A.; Uhlemann, E.; Scholz, F. Voltammetric and potentiometric studies on the stability of vanadium (IV) complexes. A comparison of solution phase voltammetry with the voltammetry of microcrystalline solid compounds. Electroanal. Int. J. Devoted Fundam. Pract. Asp. Electroanal. 1998, 10, 244-248. [CrossRef]

(C) 2020 by the authors. Licensee MDPI, Basel, Switzerland. This article is an open access article distributed under the terms and conditions of the Creative Commons Attribution (CC BY) license (http://creativecommons.org/licenses/by/4.0/). 